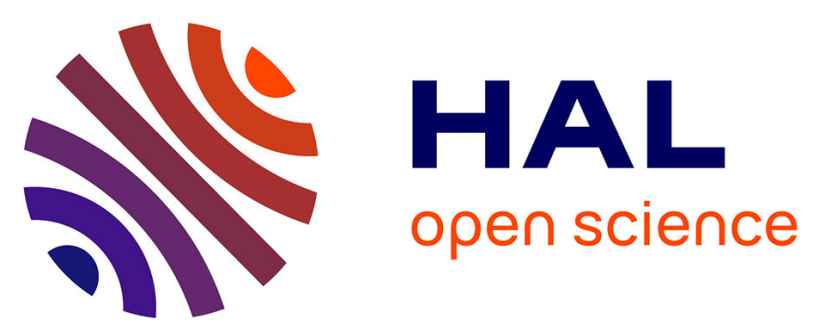

\title{
Frequency and dynamics of millennial-scale variability during Marine Isotope Stage 19: Insights from the Sulmona Basin (central Italy)
}

Eleonora Regattieri, Biagio Giaccio, Giorgio Mannella, Giovanni Zanchetta, Sebastien Nomade, Andrea Tognarelli, Natale Perchiazzi, Hendrik Vogel, Chiara Boschi, Russell Neil Drysdale, et al.

\section{To cite this version:}

Eleonora Regattieri, Biagio Giaccio, Giorgio Mannella, Giovanni Zanchetta, Sebastien Nomade, et al.. Frequency and dynamics of millennial-scale variability during Marine Isotope Stage 19: Insights from the Sulmona Basin (central Italy). Quaternary Science Reviews, 2019, 214, pp.28-43. 10.1016/j.quascirev.2019.04.024 . hal-03329520

\section{HAL Id: hal-03329520 \\ https://hal.science/hal-03329520}

Submitted on 16 Sep 2021

HAL is a multi-disciplinary open access archive for the deposit and dissemination of scientific research documents, whether they are published or not. The documents may come from teaching and research institutions in France or abroad, or from public or private research centers.
L'archive ouverte pluridisciplinaire HAL, est destinée au dépôt et à la diffusion de documents scientifiques de niveau recherche, publiés ou non, émanant des établissements d'enseignement et de recherche français ou étrangers, des laboratoires publics ou privés. 


\section{Frequency and dynamics of millennial-scale variability during Marine Isotope Stage 19: Insights}

\section{from the Sulmona Basin (central Italy)}

E. Regattieri ${ }^{1,2}$; B. Giaccio ${ }^{3}$; G. Mannella ${ }^{1}$; G. Zanchetta ${ }^{1}$; S. Nomade ${ }^{4}$; A. Tognarelli ${ }^{1}$, N. Perchiazzi ${ }^{1}$; H. Vogel ${ }^{5}$; C. Boschi ${ }^{2}$ R.N. Drysdale ${ }^{6,7}$; B. Wagner ${ }^{8}$; M. Gemelli ${ }^{1}$; P.C. Tzedakis ${ }^{9}$ ${ }^{1}$ Dipartimento di Scienze della Terra, University of Pisa, Via S. Maria 53, 56126 Pisa, Italy ${ }^{2}$ Istituto di Geoscienze e Georisorse, IGG-CNR, Via Moruzzi 1, 56126 Pisa, Italy ${ }^{3}$ Istituto di Geologia Ambientale e Geoingegneria, IGAG-CNR, Via Salaria km. 29.4 Monterotondo Rome, Italy ${ }^{4}$ Laboratoire des Sciences du Climat et de l'Environnement, IPSL, UMR8212, laboratoire CEA/CNRS/UVSQ et Université de Paris-Saclay, Gif-Sur-Yvette, France ${ }^{5}$ Institute of Geological Sciences \& Oeschger Centre for Climate Change Research, University of Bern, Switzerland ${ }^{6}$ School of Geography, University of Melbourne, Victoria 3010, Australia ${ }^{7}$ EDYTEM, UMR CNRS 5204, Université de Savoie-Mont Blanc, 73376 Le Bourget du Lac cedex, France ${ }^{8}$ Institute of Geology and Mineralogy, University of Cologne, Zülpicher Str. 49a, 50674 Köln, Germany. ${ }^{9}$ Environmental Change Research Centre, Department of Geography, University College London, England.

\section{Abstract}

Among past interglacial periods, Marine Isotope Stage (MIS) 19 is particularly interesting because its orbital geometry is very similar to that of the present interglacial. Here we present a high-resolution (subcentennial) multiproxy record covering the ca. 790-770 ka interval, i.e. the interglacial MIS 19c and the ensuing glacial inception of MIS 19b, from a lacustrine sediment sequence retrieved from the Sulmona Basin (central Italy). The record has an independent chronology based on radiometric dating of six volcanic ash layers, and the resulting age model has a mean associated uncertainty of $\pm 2.6 \mathrm{kyr}$. Variations in sediment geochemistry and mineralogy are interpreted in terms of past hydrological and 
temperature changes. Several millennial and sub-millennial events of reduced precipitation are well expressed. Comparisons with continental and marine records from the mid-latitude and sub-polar North Atlantic suggest a broad spatial expression for the observed events. Events occurring within the interglacial are not clearly associated with changes in marine proxies in the Iberian Margin, although similarities with the record from the sub-polar North Atlantic can be recognized and tentatively linked to changes in local hydrography having a downstream effect amplified by changes in atmospheric circulation. During the glacial inception, however, changes in the Sulmona record are coherent with changes in North Atlantic records, with drier events likely associated with meltwater-induced intervals of AMOC weakening. An event at ca. $785.6 \mathrm{ka}$ may also reflect oceanic changes caused by freshwater discharges from residual ice-sheets and an outburst flood, similar to the $8.2 \mathrm{ka}$ event in the Holocene.

Keywords: Stable isotope geochemistry, interglacial variability, central Italy, lacustrine succession, MIS 19

\section{Introduction}

The recovery of high-resolution records of climate variability from oceans, ice-sheets and continental archives has profoundly modified our perspective on global climate change by revealing the pervasive existence of very rapid and high-amplitude climate changes in the past (e.g. Gottschalk et al., 2015). Although such abrupt climatic changes can be triggered by different forcing, it is conceivable that human activity has likely increased their probability (Alley et al., 2003). Thus, the recognition of short-term (i.e. multi-decadal to sub-millennial), global-scale, climate variability during previous interglacial periods is of fundamental importance to provide the context of natural variability in which human-induced changes operate (Tzedakis et al., 2009).

Among older interglacial periods, Marine Isotope Stage (MIS) 19c has received particular attention due to its orbital geometry, which was very similar to that of the present interglacial (i.e., low eccentricity 
and weak precession, and similar phasing between precession and obliquity: Berger and Loutre, 1991;

49 Pol et al., 2010; Tzedakis, 2010; Tzedakis et al., 2012). Modelling studies have highlighted that this period is the best analogue for the Holocene when annual and seasonal temperatures are taken into account, although it appears less similar when the summer-half yearly insolation is considered (Yin and Berger 2010, 2012). Because MIS 19c occurred before the Mid-Brunhes Event ( $450 \mathrm{ka})$ - i.e. before the culmination of a series of changes of the global climate system resulting in the establishment of longer and deeper glacial-interglacial cycles (e.g. Head et al., 2008) - it was also characterized by slightly lower global temperatures and atmospheric $\mathrm{CO}_{2}$ concentrations with respect to the preindustrial Holocene, and possibly by higher residual global ice-volume (Bintanja et al. 2005; Bintanja and van de Wal 2008; Lüthi oscillations during MIS 19, and particularly within substage MIS 19c, have been previously reported from both marine and continental archives (Sánchez-Goñi et al., 2016; Maegakiuchi et al., 2017; Oliveira et al., 2018; Kleiven et al., 2011; Maiorano et al., 2016; Marino et al., 2015; Ferretti et al., 2015; Nomade et al., 2019). The findings of a $~ 5-k y r$ periodicity, i.e., similar to the fourth harmonic of precession, in both the coupled marine-pollen record from the southern Iberian margin (site U1385, Sánchez-Goñi et al., 2016) and in the planktonic and benthic $\delta^{18} \mathrm{O}$ record from low to mid-latitude North Atlantic and Mediterranean records (Ferretti et al., 2015; Weirauch et al., 2008; Nomade et al., 2019) led to the suggestion that variations in the tropical seasonal insolation cycle, driven by precession and its harmonics, caused periodic oscillations in the latitudinal thermal gradient. These oscillations were considered capable of altering both sea-surface conditions and westerly wind trajectories, modifying the northward transport of heat and water vapour (Sánchez-Goñi et al., 2016). Further north, however, the record of outflow speed from the Nordic Sea and the isotopic composition of surface and bottom waters from site ODP-983 (Fig. 1, Kleiven et al., 2003, 2011), located near the eastern source of North Atlantic Deep Water (NADW), shows a series of millennial-scale episodes of reduced ventilation of intermediate 
waters and reduction in deep convection strength during the whole MIS 19 period. These oscillations have been related to changes in local convection and to reduced NADW formation, leading to intervals of weakened Atlantic Meridional Overturning Circulation (AMOC) (Kleiven et al., 2011). As AMOC disruptions affect also Mediterranean climate, causing decreases in temperature and precipitation (e.g. Columbu et al., 2017; Drysdale et al., 2007; Fletcher et al., 2013; Margari et al., 2009; Regattieri et al., 2015, 2016, 2018; Tzedakis et al., 2018), the ODP-983 record points to high-latitude forcing of the observed variability. These contrasting findings thus leave open questions about oceanic and atmospheric mechanisms operating at sub-millennial scales during MIS 19 and, particularly, in its interglacial portion, and it is not clear if and how these processes can be linked to boundary conditions. Part of this uncertainty is also due to the lack of robust and independent chronologies, an issue which until now has clearly hampered our capability to asses the timing, rate, propagation and duration of changes.

Here we present a multiproxy biogeochemical record (high resolution stable oxygen and carbon isotope on lacustrine calcite, low-resolution elemental and mineralogical composition on the bulk sediment, biogenic silica content) from a stratigraphic interval containing the MIS 19c, which is part of the lacustrine succession hosted in the Sulmona Basin (central Italy, Fig. 1). Sediment proxies from Sulmona Basin record local environmental conditions, which can be linked to North Atlantic climate variability (Giaccio et al., 2015; Regattieri et al., 2015, 2016, 2017). An important feature of the Sulmona succession is the presence of numerous volcanic ash (tephra) layers interbedded within the lacustrine sediment (e.g. Giaccio et al., 2012, 2009). ${ }^{40} \mathrm{Ar} /{ }^{39} \mathrm{Ar}$ dating performed directly on those tephra layers provides robust and independent chronological constraints for the observed variability. Giaccio et al. (2015) presented the entire MIS 20 to MIS 17 interval from Sulmona, providing a relatively low-resolution stable isotope record for the 820-720 ka period and with a particular focus on the length of the MIS 19c interglacial. Here, this interglacial is investigated at higher resolution (sub-centennial) using a multi-proxy approach, 
and the record is anchored to an improved chronology. We explore the environmental expression, the pacing and the periodicities of the centennial- to millennial-scale variability revealed by the Sulmona record. We then compare this to marine records from the mid- and high-latitudes of the North Atlantic, to unravel the potential forcing and the mechanisms for short-term instability within MIS $19 \mathrm{c}$ at the extraregional scale.

\section{Site setting and stratigraphy}

The Sulmona Basin (Fig. 1) is a block-faulted intermountain depression located in the central Apennine Ridge (central Italy). The basin experienced discontinuous lacustrine sediment accumulation during the Quaternary (Cavinato and Miccadei, 2000; Giaccio et al., 2012, 2013). Its location and the geological, stratigraphic and chronological framework were described in detail in previous studies (Giaccio et al., 2009, 2012, 2013; Regattieri et al. 2015, 2016, 2017; Zanchetta et al., 2017). Briefly, the Sulmona sedimentary succession is divided into three main unconformity-bounded lithostratigraphic units (SUL6, SUL5 and SUL4-3), composed of alluvial, fluvial and lacustrine sediments. These units were chronologically constrained by magnetostratigraphy and tephrochronology (Giaccio et al., 2012, 2013, 2015; Sagnotti et al., 2014, 2016). This study focuses on the outcropping 35-43 m depth interval of the SUL6 lacustrine unit (Fig. 1). The SUL6 unit spans the period between MIS 20 and MIS 16 (820-650 ka) and encompasses the Matuyama-Brunhes geomagnetic reversal (Sagnotti et al., 2014; Mark et al., 2017). The SUL6 succession has been described by Giaccio et al. (2009), with important chronological amendments in Giaccio et al. (2013). Sediments are composed of light-coloured lacustrine calcareous marls (Freytet and Verrecchia, 2002), with up to $90 \%$ wt $\mathrm{CaCO}_{3}$ and abundant diatom remains (SOMFig. S1). The carbonate fraction is almost entirely made up of euhedral to sub-euhedral calcite crystals of $\sim 3-5 \mu \mathrm{m}$ (SOM-Fig. S1), typical of biologically-mediated inorganic carbonate precipitation from $\mathrm{Ca}^{2+}$ 
and $\mathrm{HCO}_{3}{ }^{-}$ions dissolved in surface water. Hereafter we refer to it as endogenic calcite (e.g. Jones and Bowser, 1978). The contribution of clastic carbonates from the catchment is negligible and thus has no effect on the stable isotope $\left(\delta^{18} \mathrm{O}\right.$ and $\left.\delta^{13} \mathrm{C}\right)$ composition of calcite (Regattieri et al., 2016, 2017). Several tephra layers occur within the SUL6 unit (Fig. 1) and form the basis of its chronology.

The topographic surface of the Sulmona basin is located between 340 and $400 \mathrm{~m}$ a.s.l., but its hydrology is dominated by a network of karst springs fed by recharge occurring in the surrounding mountain areas (up to 2500 m a.s.1.) (Barbieri et al., 2005; Desiderio et al., 2005a, 2005b; Falcone et al., 2008). Spring waters are characterized by a $\mathrm{pH}$ close to 7.5 , an electrical conductivity of $<500 \mu \mathrm{S}$ and a high discharge (e.g. average $7 \mathrm{~m}^{3} \mathrm{~s}^{-1}$ for the main spring, Capo Pescara), especially during snow melt in spring (Barbieri et al., 2005) and likely accounted for most of the paleolake recharge (Regattieri et al., 2015, 2016, 2017). Owing to the intense neotectonic activity, which has reshaped the local hydrography, the hydrological regime of Sulmona paleolake cannot be defined. However, based on the modern hydrography and hydrogeochemistry of the basin, as well as the observation that sediments are almost entirely composed of massive beds of endogenic calcite containing abundant and well-preserved diatom remains, it can be argued that it was a freshwater and hydrologically open basin. The stable isotope composition of the endogenic calcite is also consistent with this interpretation (Regattieri et al., 2015, 2016, 2017).

Local precipitation averages $\sim 700 \mathrm{~mm} / \mathrm{yr}$ but increases up to $1200 \mathrm{~mm} / \mathrm{yr}$ at high altitude. Rainfall is unevenly distributed, showing maxima during autumn and winter, and minima during the summer season. Winter precipitation is mostly related to north-westerly circulation. Cyclones originate over the North Atlantic and take a mid-latitude storm track, following a prevailing NW-SE direction (Reale and Lionello, 2013). Secondary cyclones, often associated with the passage of major cyclones north of the Mediterranean, form within the basin and especially in the Gulf of Genoa, the most important Mediterranean cyclogenetic centre (Lionello et al., 2006). The amount of winter precipitation reaching the Mediterranean is influenced by several large-scale atmospheric patterns, which induce changes in 
storm-track activity. In particular, at multiannual and decadal scales, the amount of winter precipitation

143 is inversely correlated with the North Atlantic Oscillation (NAO) index (e.g. Lopez-Moreno et al., 2011;

144 Ulbrich et al., 2012; Cullen et al., 2002), because during negative NAO phases westerly storm tracks are 145 shifted southward and allow a greater penetration of storms into the basin, and because negative NAO 146 phases enhance Mediterranean cyclogenesis (Ulbrich et al., 2012). Summer droughts are due to the 147 expansion of the Azores high (Xoplaki et al., 2003; Ulbrich et al., 2012 and references therein). Summer 148 precipitation is scarce and mostly related to local heat lows, which owe their genesis to thermal heating 149 overland, and to evaporation and convection influenced by the surrounding mountain topography.

\section{Methods}

\subsection{Sampling and stable isotope analyses}

152 The studied interval comprises three distinct outcropping and partially overlapping sections that are 153 lithostratigraphically correlated through clearly distinguishable tephra horizons (Fig. 1). The composite 154 section is eight metres thick and was sampled for stable isotope analyses at $2.5 \mathrm{~cm}$ vertical resolution, 155 for a total of $\sim 320$ samples. Sample preparation followed the procedure described in Regattieri et al. 156 (2015). Stable isotope analyses were performed at the Stable Isotope Laboratory of the Institute of 157 Geosciences and Earth Resources of the Italian National Research Council (IGG-CNR, Pisa, Italy) with 158 a Gas Bench II (Thermo Scientific) coupled to a Delta XP IRMS (Finnigan), following the method 159 presented in Regattieri et al. (2016). Sample results are reported on the VPDB scale and calibrated against 160 the international standards NBS-18 and NBS-19. Analytical uncertainties were $0.17 \%$ and $0.15 \%$ for $161 \delta^{18} \mathrm{O}$ and $\delta^{13} \mathrm{C}$ respectively $(2 \sigma)$.

\subsection{Elemental, mineralogical and biogenic silica analyses} X-ray fluorescence spectrometry (XRF) and X-ray powder diffraction (XRPD) analyses were performed 164 on untreated leftover powders of the stable isotope analyses at the Earth Sciences Department of the 
University of Pisa (Italy). Elemental analyses were conducted with a NITON XL3t GOLDD + hand-held XRF unit (HHXRF, see Gemelli et al., 2015 for performance), following the analytical procedure for sediment samples described in Regattieri et al. (2016).

Mineralogical composition was investigated on 36 unevenly spaced samples through XRPD analyses with a Bruker D2 Phaser diffractometer equipped with a Lynxeye fast detector. Phase identification was obtained with the Bruker Diffrac-Suite EVA and Topas-Academic software (Coelho, 2018). A semiquantitative estimation of mineral abundances (quartz/calcite ratio, qz/ct hereafter), was calculated with the abovementioned software as the ratio between spectral peak areas of quartz and calcite.

Biogenic silica (bSi) concentrations were measured on the same samples analysed with XRF, using Fourier transform infrared spectroscopy (FTIRS) at the Institute of Geological Sciences, University of Bern, Switzerland. Analyses were performed using the method described in Vogel et al. (2008) and adopting the sample preparation protocol of Vogel et al. (2016). Calibration, accuracy and precision are detailed in Meyer-Jacob et al. (2014).

\subsection{Ar/Ar dating and age modelling}

The Bayesian age model (Fig. 2) is based on ${ }^{40} \mathrm{Ar} /{ }^{39} \mathrm{Ar}$ dating of six tephra layers (Fig. 1 and Table 1). Four of these tephra layers occur within the interval analysed in this study (35-43 m depth, Fig. 1), while the remaining two occur in close proximity (at $46.14 \mathrm{~m}$ and $29.70 \mathrm{~m}$ ) and were employed to better constrain the age-modelling procedure. For five of the six tephra, ages are from Giaccio et al. (2015), here recalculated using the new Optimisation Model age for the ACs monitor standard (1.891 Ma; Niespolo et al., 2017). A new ${ }^{40} \mathrm{Ar} /{ }^{39} \mathrm{Ar}$ dating for the SUL2-19 tephra, obtained at the CNRS-LSCE (Centre National de la Recherche Scientifique, Laboratoire des Sciences du Climat et de l'Environnement, Gif Sur Yvette, France), is presented here (Fig. 2). Analytical procedures are as described in Giaccio et al. (2015). Details concerning the analytical procedure and the full dataset are both given in supplementary material (SOM text 1 and SOM Table 1). This new age is calibrated against 
the ACs-2 age of 1.1891 (i.e. FCs at $28.294 \mathrm{Ma}$; Niespolo et al., 2017) and calculated using the total K decay constant of Renne et al. (2010). The Bayesian age model (Fig. 2) was constructed using the Bacon software (Blaauw et al., 2011). "A priori" settings were chosen to accommodate the actual mean sedimentation rate $(28.7 \mathrm{yr} / \mathrm{cm})$, and to allow for larger variations around the mean value. Successive calculations with different settings held statistically indistinguishable age-depth relationships, although the current model minimizes the difference between radiometric and modelled tephra ages (Table 1).

\subsection{Wavelet analyses}

196 Continuous wavelet analyses (CWT) was performed on $\delta^{18} \mathrm{O}$ data series for the whole interval between $197800 \mathrm{ka}$ and $750 \mathrm{ka}$, including lower resolution data from Giaccio et al. (2015) for the periods not covered 198 by the new record, employing a self-implemented Matlab code described in Tognarelli et al. (2018) and in Tognarelli (2018). No filtering was performed before the wavelet analysis in order to preserve the original frequency content of the input data. Only a linear interpolation is applied to the data to produce wavelet power spectrum were computed by means of a chi-square test with two degrees of freedom, where the null hypothesis assumes the that the local wavelet power spectrum corresponds to the rednoise spectrum with a lag-1 coefficient of 0.73 . Power bands for the most intense periodicities were extracted from the spectra through the inverse continuous wavelet transform.

\section{Results and discussion}

4.1. Chronology

Full analytical details for the 35 individual sanidine crystals of the SUL2-19 tephra are given in Table S1. Among the 35 analysed, 29 yielded ages overlapping within uncertainty, allowing the calculation of 210 a weighted mean age of $784.7 \pm 2.4 \mathrm{ka}(2 \sigma$ including J uncertainty) (Fig. 2 and Table 1$)$. 
211 According to the age model presented in Fig. 2, the new high-resolution $\delta^{18} \mathrm{O}$ record presented in this 212 study spans the $769.8 \pm 2.2$ ka to $789.9 \pm 2.1$ ka period. The mean associated uncertainty of the record is $2132.6 \mathrm{kyr}$, ranging from 2.1 to $2.8 \mathrm{kyr}$ (Fig. 2). The resulting average temporal resolution of the stable 214 isotope series is 60 years, while the temporal resolution of XRF and bSi analyses is 230 years. XRD 215 samples are not evenly spaced, but on average their resolution is $\sim 600$ years. The sedimentation rate is 216 on average $0.45 \mathrm{~mm} / \mathrm{yr}$, ranging from $0.18 \mathrm{~mm} / \mathrm{yr}$ to $0.73 \mathrm{~mm} / \mathrm{yr}$.

\section{4.2. Proxy interpretation}

218 Different sediment properties presented in this work $\left(\delta^{13} \mathrm{C}, \delta^{18} \mathrm{O}\right.$, Ca content, biogenic silica content 219 mineralogical composition, Fig. 3) have been measured and discussed previously for other lacustrine 220 intervals in Sulmona (Giaccio et al., 2015; Regattieri et al., 2015, 2016, 2017), so their paleoclimatic 221 interpretation is only briefly outlined here and the reader is referred to previous works for more detailed 222 explanation.

\subsubsection{Oxygen and carbon stable isotopes}

224 The oxygen stable isotope composition $\left(\delta^{18} \mathrm{O}\right)$ of lacustrine, biologically-induced, endogenic calcite 225 depends on temperature and oxygen isotopic composition of the lake surface water (e.g. Leng and 226 Marshall, 2004). In the Mediterranean region, the temperature effect during carbonate precipitation (ca. $227-0.24 \% /{ }^{\circ} \mathrm{C}$; Kim and O’Neil, 2007) is negligible, because it is counterbalanced by a gradient of ca. $228+0.3 \% /{ }^{\circ} \mathrm{C}$ observed between mean annual $\delta^{18} \mathrm{O}$ of meteoric precipitation and temperature (Bard et al., 229 2002). The $\delta^{18} \mathrm{O}$ of lake water depends on the $\delta^{18} \mathrm{O}$ of precipitation and on the precipitation/evaporation 230 (P/E) ratio (e.g. Leng and Marshall, 2004). The $\delta^{18} \mathrm{O}$ of Mediterranean precipitation has a strong 231 empirical relationship with the amount of rainfall (ca. $-2 \%$ o $/ 100 \mathrm{~mm}$ ), with lower values related to 232 increased precipitation and higher values related to reduced precipitation (Bard et al., 2002). Previous 
studies on lacustrine carbonates from the Sulmona Basin have shown that the influence of lake water evaporation for the final calcite $\delta^{18} \mathrm{O}$ is negligible, likely due to the large and sustained karstic recharge, to presumable hydrologically open conditions and relatively short water residence times within the lake. Therefore, the $\delta^{18} \mathrm{O}$ composition of endogenic calcite at Sulmona can be used as a first-order proxy for precipitation amount in the high-altitude catchment of the karst recharge system (Giaccio et al., 2015; Regattieri et al., 2015, 2016, 2017). Changes in isotopic composition driven by changes in the source area of moisture always contribute to changes in the $\delta^{18} \mathrm{O}$ of precipitation, and thus of precipitated carbonates. However, these variations have proven to be significant especially during glacial/interglacial transitions (e.g. Marino et al., 2015), but can be considered negligible during interglacial periods such as the period discussed here (Tzedakis et al., 2018).

The stable carbon isotope composition of lacustrine endogenic calcite derives from that of the dissolved inorganic carbon (DIC) of the lake water (Whittington et al., 2015; Zanchetta et al., 2012, 2018;). The DIC of the Sulmona paleolake was likely significantly influenced by the input of the large karst springs recharging the basin, which today show higher $\delta^{13} \mathrm{C}_{\mathrm{DIC}}\left(\delta^{13} \mathrm{C}_{\mathrm{DIC}(\mathrm{karst})}\right)$ compared to smaller and more surficial springs, due to the longer rock-water interaction times (Falcone et al., 2008). Variations in $\delta^{13} \mathrm{C}_{\mathrm{DIC}(\mathrm{karst})}$ are related to rainfall and temperature fluctuations, with dry/cool periods characterized by reduced soil OM stocks and longer water residence times, leading to higher $\delta^{13} \mathrm{CDIC}($ karst). Conversely, warmer and wetter conditions promote soil and vegetation development and a faster water flow, leading to more negative $\delta^{13} \mathrm{C}_{\mathrm{DIC}(\mathrm{karst}),}$ as commonly inferred from speleothem studies (e.g. Genty et al., 2002; Regattieri et al., 2014). Within the lake, the $\delta^{13} \mathrm{CDIC}_{\text {(karst) }}$ signal is mediated by additional processes, which involve equilibration with atmospheric $\mathrm{CO}_{2}$, photosynthetic ${ }^{12} \mathrm{C}$ uptake, and consumption and recycling of organic matter in the water column as well as in the sediment. These processes largely depend on the lake hydrological budget and settings (e.g. Leng and Marshall, 2004). In our record, a generally weak covariance between $\delta^{13} \mathrm{C}$ and $\delta^{18} \mathrm{O}$ is observed, especially for the decreasing trend at the beginning of the 
257 record and for a similar interval of enriched values at ca. $772 \mathrm{ka}$ (Fig. 3). On the whole, $\delta^{13} \mathrm{C}$ and $\delta^{18} \mathrm{O}$ 258 also show a weak though significant statistical correlation ( $r=0.37$, Fig. 4), though is visually clear that 259 their relationship change during different intervals. A positive covariation of the two isotopes is usually 260 observed in hydrologically closed lakes (e.g. Talbot and Kelts, 1990). In hydrologically open lakes, 261 where calcite precipitation is mediated by primary productivity, an inverse relationship between $\delta^{13} \mathrm{C}$ and $262 \delta^{18} \mathrm{O}$ is instead expected (e.g. Talbot and Kelts, 1990). The current hydrology of the Sulmona Basin and 263 the negligible effects of evaporation on the $\delta^{18} \mathrm{O}$ signal strongly suggest hydrologically open conditions 264 for the Sulmona Lake, and relatively short water residence times within the lake. Thus, the weak 265 covariance between $\delta^{13} \mathrm{C}$ and $\delta^{18} \mathrm{O}$, rather than an indication of hydrological closure, likely indicates that 266 the $\delta^{13} \mathrm{C}_{\mathrm{DIC}(\mathrm{karst})}$ signal is dominant on the final $\delta^{13} \mathrm{C}$ of calcite, and that the evolution of the $\delta^{13} \mathrm{C}_{\mathrm{DIC}}(\mathrm{karst})$ 267 is modulated by climate conditions, mostly via the regulation of soil $\mathrm{CO}_{2}$ leached to the lake (Zanchetta 268 et al., 2018). However, a divergence is apparent in the long-term trends of the two isotope time series, 269 with progressively more negative $\delta^{13} \mathrm{C}$ values corresponding to increasing $\delta^{18} \mathrm{O}$ (Fig. 3). This decoupling 270 could be related to the increasing influence of in-lake processes compared to that of karst recharge, which 271 may possibly decrease. Alternatively, the trend towards more negative $\delta^{13} \mathrm{C}$ values can be explained by 272 the slow post-glacial development of soils in the catchment, supplying more ${ }^{13} \mathrm{C}$ depleted $\mathrm{CO}_{2}$, following 273 the progression of the interglacial, as already observed for speleothem records from high-altitude 274 recharge areas (Drysdale et al., 2005, Regattieri et al., 2014, Zanchetta et al., 2007).

\section{$275 \quad$ 4.2.2 Productivity and detrital proxies}

276 In the Sulmona lacustrine sediment, Ca occurs mostly as endogenic calcite, as demonstrated by previous 277 studies and by SEM microphotographs of the sediment (SOM, Fig. S1). Endogenic calcite precipitates 278 through algal fixation of $\mathrm{CO}_{2}$, thus in this context $\mathrm{Ca}$ content is an indirect proxy for lake primary 279 productivity. Biogenic silica (bSi) in the sediment primarily derives from diatom frustules and thus also 
provides information on primary productivity (Vogel et al., 2010). Rising spring and summer temperatures and nutrient availability promote primary productivity. Calcite precipitation rate depends also on $\mathrm{HCO}_{3}{ }^{-}$and $\mathrm{Ca}^{2+}$ concentrations in the lake water, with enhanced ion supply through soil/epikarst dissolution processes and high soil $\mathrm{CO}_{2}$ production and leaching, both leading to higher dissolved ion content, during wetter and warmer periods (e.g. Francke et al., 2016). General agreement is observed between $\mathrm{Ca}$ and bSi content, but some differences are apparent (Fig. 3). At Sulmona, volcanic material from tephra deposition in the lake and mobilization of volcanoclastic deposits in the catchment was likely an important source for the Si and Fe needed for diatom growth. The single sample with high bSi content at ca. $789 \mathrm{ka}$ occurs in close proximity (i.e. within $5 \mathrm{~cm}$ ) of tephra T22. Tephra deposition following large eruptions can trigger short-term diatom blooms, which are not necessarily climate-related (Cvetkoska et al., 2015; D'Addabbo et al., 2015). It is also interesting that the main rise in bSi seems to and $\mathrm{Ca}^{2+}$ ions were less important for $\mathrm{Fe}$ and $\mathrm{Si}$ concentrations in water. This would imply a stronger dependence from rainfall fluctuations for the Ca content, whereas diatom growth (i.e. bSi content) would respond mostly to temperature variations, with superimposed fluctuations influenced by occasional Fe and Si inputs.

XRPD analyses of the bulk sediment reveal the predominant presence of calcite, accompanied only by a small amount of quartz. Quartz is typically present in small quantities in limestone. When carbonate rock dissolves, quartz remains in the soil together with other silicate minerals and Fe oxides and hydroxides. These can be transported to the lake by runoff, which is enhanced when the vegetation cover is reduced. 
Part of the quartz can also be linked to erosion and transport processes from silicate rocks in the lake catchment, but these rocks are virtually absent in the Sulmona Basin, thus their contribution is likely to be insignificant. Quartz can also have an aeolian origin, as suggested for quartz-rich loess deposits along the Apennines (Giraudi et al., 2013) and for quartz grains in central Italy maar lake sediments (Narcisi, 2000). Sourcing and transport of aeolian particles is also enhanced when the vegetation is less developed (Boretto et al., 2017). Thus, at Sulmona the quartz/calcite ratio (Fig. 3) can be considered a simple, semiquantitative way to express variations in soil erosion in the catchment and/or in aeolian input to the lake, with higher ratios indicating decreased erosion and/or reduced aeolian transport, likely both arising from vegetation development under wetter and warmer conditions.

\subsection{Paleoenvironmental and paleohydrological evolution during MIS 19 in the Sulmona Basin.}

Based on the interpretations introduced above, the new high-resolution $\delta^{18} \mathrm{O}$ record for MIS $19 \mathrm{c}$ shows rapidly increasing precipitation after $788 \mathrm{ka}$ (Fig. 3). This trend follows that observed in the lowresolution $\delta^{18} \mathrm{O}$ time-series by Giaccio et al. (2015; Fig. 3) and represents the latest part of the deglaciation occurring between MIS 20 and MIS 19. The deglaciation is accompanied by rising lake primary productivity (increasing $\mathrm{Ca}$ and $\mathrm{bSi}$ ) and by enhanced supply of soil $\mathrm{CO}_{2}$ (lower $\delta^{13} \mathrm{C}$ ), both indicating warmer temperature, and by a strong decrease in the clastic/aeolian input to the lake (decreasing qz/ct), likely arising from the increasing vegetation cover (Fig. 3). Peak precipitation was reached at ca.786.0 ka, but was rapidly interrupted by a prominent, $\sim 0.8 \mathrm{kyr}$ long, drier period starting at 785.6 ka (Fig. 3, Table 2). This event, denoted by the Roman number I in Figure 3 and in Table 2, is clearly expressed in all the other proxies. Precipitation increased again at $784.3 \mathrm{ka}$ and remained relatively high until ca. $779.0 \mathrm{ka}$. Within this period, however, two events of reduced precipitation are apparent (II and III; Table 2, Fig. 3). Between $779 \mathrm{ka}$ and $777 \mathrm{ka}$, precipitation and primary productivity decrease and conditions remain consistently drier and colder compared to the previous interval. Three 
further events of increasing dryness and reduced productivity occur between $779 \mathrm{ka}$ and $775 \mathrm{ka}$ (IV, V, VI; Table 2, Fig. 3). Aside from event I, changes of $\delta^{18} \mathrm{O}$ values during event II to VI are of low magnitude (0.2-0.4\%o). However, all of them are coherently expressed by several data points (Fig. 3), suggesting that they represent a real short-term, low-amplitude hydrological variability. These events (II to VI) are not clearly expressed by the other proxies, likely due to their lower temporal resolution and to a more subdued response of these properties during period of overall wet conditions. From $773.0 \mathrm{ka}$, there is a large and abrupt decrease in precipitation, immediately followed by increased clastic input and reduced primary productivity lasting until $771.2 \mathrm{ka}$ (event VII in Fig. 3, Table 2). This period is followed by an increase in precipitation and productivity (Fig. 3), although erosion rates in the catchment remain quite high until the end of the high-resolution section at $769.8 \mathrm{ka}$.

\subsection{Regional significance of the Sulmona record and potential links with North Atlantic variability}

Few paleoclimatic records spanning MIS 19c with a temporal resolution comparable to our record exist from the Mediterranean and the North Atlantic regions (Nomade et al., 2019, Ferretti et al., 2015; Sánchez-Goñi et al., 2016), and none possesses an independent radiometric chronology. The coupled marine-pollen record from marine core U1385 on the southern Iberian Margin (Hodell et al., 2015; Sánchez-Goñi et al., 2016, Figs. 5 and 6) provides a relatively high-resolution, multi-proxy biogeochemical record for the MIS 19 (resolution of $\sim 300 \mathrm{yr}$ for pollen and alkenones and of $\sim 160-200 \mathrm{yr}$ for planktonic and benthic stable isotope composition), capable of capturing both orbital and millennialscale climatic change (Sánchez-Goñi et al., 2016). The U1385 chronology relies on the climatostratigraphic tuning to the global benthic stack LR04, and has a mean absolute uncertainty of $\sim 5$ ka (Lisieki and Raymo, 2005). The benthic $\delta^{18} \mathrm{O}$ from U1385 shows that MIS 19 ranges from 791 ka to $758 \mathrm{ka}$, and that MIS 19c ends at ca. $775 \mathrm{ka}$. The pollen record from the same core shows that the onset of the terrestrial interglacial (Tajo interglacial) occurs at ca. $787 \mathrm{ka}$, slightly after the onset of MIS 19c, 
whereas its end is almost coincident with that of the benthic substage (Sánchez-Goñi et al., 2016). Seven events of forest contraction have been identified within MIS 19 (Sánchez-Goñi et al., 2016, Fig. 5). Of these, only those occurring after ca. $770 \mathrm{ka}$, i.e. well after the interglacial, appeared to be coupled with changes in oceanic conditions. For the other events, a warm sea/cold-dry land decoupling was observed and proposed to represent an increased latitudinal thermal contrast causing a northward shift in westerly wind trajectories. By analogy with the present positive mode of the NAO, this would have caused reduced precipitation over southern Iberia (Sánchez-Goñi et al., 2016), and by extension in the central and eastern Mediterranean region (e.g. Regattieri et al., 2019; Smith et al., 2016). Frequency analysis of the whole U1385 record shows evidence for a strong 5-kyr periodicity (Sánchez-Goñi et al., 2016). This led to the conclusion that the variability observed in the pollen record can be attributed to precession harmonicsrelated changes in yearly solar radiation in the tropics, relaxing or amplifying the thermal latitudinal contrast and affecting mostly the strength of low-latitude low-pressure systems and thus atmospheric circulation (Sánchez-Goñi et al., 2016).

The comparison between the Sulmona and the U1385 records reveals a striking similarity between the lacustrine $\delta^{18} \mathrm{O}$ and Mediterranean forest pollen percentage (Fig. 5). The intervals of forest reduction in the pollen record correspond to dry periods in the Sulmona record, where the higher resolution allows a better exploration of their internal structure and the identification of additional events (Fig. 5). Rainfall amount exerts a dominant control on the composition of southern European vegetation (e.g. Quezel et al., 2002; Gouveia et al., 2008) and the oxygen isotope composition of Mediterranean continental carbonates (lacustrine sediment and speleothem; e.g. Bard et al., 2002; Roberts et al., 2008), with forest expansion and ${ }^{18} \mathrm{O}$-depleted precipitation associated with higher rainfall amount. This provides a basis for creating a common time scale between the Sulmona $\delta^{18} \mathrm{O}$ and the Iberian margin pollen records, an approach already employed to transfer the radiometric chronology of a central Italy $\delta^{18} \mathrm{O}$ speleothem record to a marine pollen record covering the Last Interglacial (Tzedakis et al., 2018). Thus, we aligned 
(sensu Govin et al., 2015 and Zanchetta et al., 2016) the peaks in Mediterranean pollen taxa corresponding to the Tajo interglacial and to the two subsequent forest expansions from U1385 to their analogous wet interstadials from the Sulmona $\delta^{18} \mathrm{O}$ record (Fig. 5 and SOM-Table 2). This adjustment produces minor shifts (average $\sim 1.7 \mathrm{kyr}$ ) in the U1385 chronology, fully within the absolute chronological uncertainty, but it allows us to better constrain the age of Marine sub-Stage MIS 19c (starting at $791 \mathrm{ka}$ ) and that of the terrestrial interglacial as defined by Sánchez-Goñi et al. (2016) in southern Iberia $(787.6$ - $776.9 \mathrm{ka})$. According to the Sulmona chronology, the Tajo interglacial in U1385 lasts $10.7 \pm 2.8 \mathrm{ka}$, which is close to a half a precession cycle. A similar duration (i.e. $11.5 \pm 3.4 \mathrm{kyr}$ long) for the MIS19c interglacial was recently proposed by Nomade et al. (2019) based on the marine section of Montalbano-Jonico (Southern Italy). The alignment between the U1385 pollen record and the Sulmona isotope record allows us to explore whether the dry events from Sulmona can be associated with changes in marine proxies (Fig. 6). It is worth noting that the resolution of stable-isotope analyses from both archives is higher than that of the pollen and SST records, permitting a more detailed sea-land comparison once a common time scale is defined. For the major events occurring at ca. $772 \mathrm{ka}, 765 \mathrm{ka}$ and 760 ka based on the Sulmona chronology (VII, IIX and IX in Fig. 6), rainfall reductions are in phase with prominent changes in oceanic conditions, i.e. decreasing benthic $\delta^{13} \mathrm{C}$ and sea surface temperature (SST), increasing planktonic $\delta^{18} \mathrm{O}$ and $\mathrm{C}_{37: 4}$-based freshwater index, Fig. 6). These events have been correlated to intervals of sub-polar Ice Rafted Debris (IRD) deposition (Sánchez-Goñi et al., 2016). The freshwater flux associated with IRD deposition is known to induce intervals of AMOC slow-down or interruption (e.g. McManus et al., 1999). The resulting decrease in SST at the mid-latitudes reduced evaporation and advection of air masses rich in moisture towards the Mediterranean region, leading to basin-wide colder and drier intervals during glacial and transitional periods (i.e., glacial/interglacial transition and glacial inception), (e.g. Drysdale et al., 2007; Fletcher et al 2013; Margari et al., 2009; Regattieri et al., 2015, 2016; Sinopoli et al., 2018; Tzedakis et al., 2004). Together with reduced 
precipitation, for the event at ca. $772 \mathrm{ka}$ the other proxies from Sulmona also show marked decreasing

400

401

402

403

404

405

406

407

408

409

410

411

412

413

414

415

416

417

418

419

420

421

422

primary productivity in the lake and in the surroundings soils, coherently indicating decreasing temperatures (Fig. 3).

For events not associated with iceberg discharges in the North Atlantic (I to VI in Fig. 6), marine proxies do not show major oscillations, but rather a low-amplitude variability (Fig. 6). The event I at ca. 786 ka appears to correspond to a decrease in planktonic $\delta^{18} \mathrm{O}$ comprising several data points, followed by a similar increase (Fig. 6). Further, the benthic $\delta^{13} \mathrm{C}$ and the SST records show coincident slightly decreasing values (Fig. 6), suggesting that this event may be connected to a slight weakening of AMOC activity. To some extent, a similar configuration is apparent also for the event at ca. $782 \mathrm{ka}$ (Fig. 6), although it is not expressed by the benthic $\delta^{13} \mathrm{C}$ record. For the other events, the relatively low resolution and the low intensity variability hampers the possibility of a detailed correlation, though slightly increased planktonic $\delta^{18} \mathrm{O}$ values seem to correspond to event VI (Fig. 6).

To better define the relationship between Mediterranean hydrology and ocean conditions during the interglacial, we compare our $\delta^{18} \mathrm{O}$ record to the high-resolution (average 250 years) multiproxy record from ODP-983 from the Gardar Drift, south of Iceland (Figs. 1 and 8, Kleiven et al., 2011). The Gardar Drift is a key location to assess changes in NADW formation and related perturbations of AMOC circulation (Kleiven et al., 2003, 2011). There, changes in deep hydrography are highlighted by decreases in outflow speed and intensity from the Nordic Sea, recorded by changes in sediment grain size and sorting (Kleiven et al., 2011; McCave and Hall, 2006) and by fluctuations in the benthic $\delta^{13} \mathrm{C}$ record (Oppo and Lehman, 1993). During warm periods, the site is bathed at depth by the vigorous outflow of the Iceland-Scotland Overflow Water (ISOW), an essential component of the AMOC circulation that modulates European climate (Bianchi and McCave, 2000). Warm salty surface waters are advected northward, where the site of deep convection and NADW formation is located (Knorr and Lohmann, 2007; Schmidt et al., 2004). At site 983 interglacial circulation appears substantially more stable 
compared to glacial periods, when the centre of NADW formation shifted from the present Nordic Seas position to the subpolar North Atlantic (Oppo and Lehman, 1993). However, all the warm stages of the Middle Pleistocene show the occurrence of rapid shifts in the style or intensity of deep-water convection, implying internal mechanisms that may generate AMOC instabilities also during periods of low icevolume (Kleiven et al., 2003).

We first exported our independent chronology to the marine record. As discussed, events of IRD deposition in the North Atlantic impact AMOC circulation and, as a consequence, the Mediterranean hydrological cycle. Thus, we align the end of the IRD peaks occurring during the glacial inception to the corresponding onset of wet interstadials in our record (Fig. 7 and SOM-Table 2), and the end of the last IRD peak occurring during the glacial termination with the onset of the terrestrial interglacial (Fig. 8 and SOM-Table 2). As an independent test for alignment, we consider the correlations between U1385 and ODP-983, both reported on the Sulmona chronology (Fig. 7). The onset and demise of the major intervals of IRD deposition in the subpolar region show good chronological agreement with intervals of increased $\mathrm{C}_{37: 4}$ based fresh-water index (Fig. 7), despite the low resolution of the latter curve. Also, the stadialinterstadial pattern of the two planktonic $\delta^{18} \mathrm{O}$ time-series is consistent. Decreasing/increasing $\delta^{18} \mathrm{O}$ planktonic values can be linked to increasing/decreasing temperature or to decreased/increased salinity. In the ODP-983 record, IRD events are accompanied by decreasing planktonic $\delta^{18} \mathrm{O}$ values (Fig. 7), likely due to the influence of ${ }^{18} \mathrm{O}$-depleted meltwater releases, whereas on the Iberian margin the freshwater flux is associated with decreasing SST and related increases of planktonic $\delta^{18} \mathrm{O}$ values (Fig. 7).

Now that a common time scale is defined, we can check in detail if intra-interglacial continental events have a counterpart in the sub-polar record (Fig. 8). As with U1385, the ODP-983 record shows only a subdued variability during the interglacial. However, the event I at ca. $786 \mathrm{ka}$ is marked by a significant reduction in deep-water ventilation (lower benthic $\delta^{13} \mathrm{C}$ ), and by a decrease in outflow strength (lower sortable silt percentage; Fig. 8), suggesting the occurrence of a short-term AMOC perturbation. It also 
corresponds to a slight and steep decrease and a subsequent sudden increase in planktonic $\delta^{18} \mathrm{O}$ (Fig. 8).

448 The other events recorded at Sulmona do not clearly correlate with variations in ODP-983 proxies due 449 to the subdued variability of the latter record. However, considering the combined age uncertainties, a 450 similar pattern between the deep outflow from the Nordic Sea (represented by the sortable silt percentage, 451 Fig. 8) and the Sulmona $\delta^{18} \mathrm{O}$ record is apparent. Fluctuations in the sortable silt percentage are small, 452 but a similar variability observed during the Holocene in the record of nearby marine core NEAP-15K 453 (Bianchi and McCave, 2000) has been considered significant, and interpreted as reflecting subtle changes 454 in the ISOW strength.

Our analyses point to different forcing for millennial and sub-millennial variability during MIS 19. After 457 the interglacial and following $772 \mathrm{ka}$, coherent changes in marine and continental proxies (Figs. 6 and 8) 458 indicate a rapid transfer of northern North Atlantic climate changes into the western Mediterranean 459 region. The North Atlantic record suggests that this variability arises from interactions between ice-sheet dynamics (testified by the IRD-C $37: 4$ events) and the AMOC. Within the interglacial, event I centred at ca. $786 \mathrm{ka}$ also shows a coupling between continental and marine conditions (Figs. 6 and 8). This rainfall reduction and forest contraction in southern Europe appears to be related to a temporary, low-intensity AMOC disturbance. The marine records show lower benthic $\delta^{13} \mathrm{C}$ at both sites, decreased SST on the Iberian Margin, and reduced convection in the northern North Atlantic (Figs. 6 and 8). Concomitant decreasing $\delta^{18} \mathrm{O}$ planktonic values in the marine records can be related to increasing temperature, which is in contrast with the SST record from the Iberian margin, or to decreased salinity, potentially related to freshwater influx. This evidence suggests that this event could be an analogue to the Holocene $8.2 \mathrm{ka}$ event, i.e., the final outburst from the proglacial lake Agassiz (e.g. Alley et al., 1997; Alley and Angustsdottir, 2005; Barber et al., 1999; Clarke et al., 2004). The related freshening of surface water 
impacted convection in the Labrador Sea, where the western centre of NADW production is located, producing a slowdown of the AMOC, and a consequent widespread climate anomaly. The occurrence of similar events has been also postulated for interglacials other than Holocene, as for the Last Interglacial (Nicholl et al., 2012; Galaasen et al., 2014), and the MIS 11 (Koutsodendris et al. 2012). Interestingly, although the lower resolution and the chronological mismatching prevent a secure correlation, a shortlived period of climate perturbation is apparent within several MIS 19c records. Indeed, a cooling event in the early part of the interglacial has been reported from the pollen record of the Montalbano Jonico section (Southern Italy, Bertini et al., 2015; Marino et al., 2015), and from a marine core from the Osaka Bay (Japan, Maegakiuchi et al., 2016). For the other intra-interglacial events, the coupling between terrestrial and marine proxies, especially those from the Iberian Margin, is not as clear, perhaps pointing to a different forcing. Changes in north-westerly circulation and related moisture transport are likely involved, but the ultimate causes for these atmospheric oscillations remain currently largely unexplained. To explain changes in local convection observed at the ODP-983 site during interglacial intervals, it has been proposed that enhanced sea-ice formation south of Iceland might have created an unstable density stratification in the water column, causing a slow-down in the advection of southern warm waters, and an attendant cooling over the northern North Atlantic, with a downstream effect amplified by changes in the atmospheric circulation (Kleiven et al., 2011). State-of-the-art coupled models also have shown the occurrence of positive feedbacks between the atmosphere and the sea-ice, with stochastic atmospheric changes inducing AMOC weakening and larger sea-ice cover, leading to cooling in the sub-polar and to strengthening of high-pressure system at the high latitudes (Drijfhout et al., 2013; Kleppin et al., 2015). The similarity between the oxygen record from Sulmona and the record of deep-water ventilation and outflow speed from the Nordic Sea (Fig. 8) suggests that this cooling impacted atmospheric circulation patterns also in the Mediterranean by altering the intensity and trajectories of westerly winds. In particular, it would have led to a northern shift of the westerlies, reducing their penetration, and thus the 
amount of rainfall, within the Mediterranean Basin. This would have resembled an atmospheric configuration similar to the positive state of the NAO.

Further insights on the ultimate forcing for the MIS 19 millennial and sub-millennial variability can be obtained from the dominant periodicities resulting from the Sulmona CWT analyses and by analysing the timing and pacing of events. The real wavelet power spectrum for the oxygen time series, including low-resolution data from Giaccio et al. (2015) for the younger (i.e. after $770 \mathrm{ka}$ ) and older portions (prior to $790 \mathrm{ka}$ ) of the record, is shown in Fig. 9. Both the spectrum and the curves for the most energetic periodicities (Fig. 9) show prominent changes throughout the investigated period and especially between the transitional periods (deglaciation and glacial inception) and the interglacial portion of the record. Considering only those periodicities which i) are enclosed in the region of greater than $95 \%$ confidence, ii) fall above the COI and iii) are longer than the uncertainty associated to the record (median $2.5 \mathrm{kyr}$ ), two main wavelength bands can be recognized. Starting from the longest, a $\sim 5.0-6.0$ kyr cycle (Fig. 9) can be observed throughout the investigated period. Periodicities of ca. 5-6 kyr, i.e. similar to the fourth precession harmonic have been observed in several MIS 19 records (Sánchez-Goñi et al., 2016; Ferretti et al., 2016; Weirauch et al., 2008; Nomade et al., 2019). However, in our record the intensity of this periodicity almost vanishes in the middle portion of the interglacial, especially between ca. 784 and 778 ka (Fig. 9). Further, the pacing of both intra- and post-interglacial events is non-stationary, ranging from ca. 4 to 2 kyr (Table 2). The non-stationarity is evident whatever approach is used to define the temporal relationships among different events, i.e. either when the onset, the mid-point and the end of events are considered. The length of events is also rather variable (Table 2), with an average duration between 0.9 and $0.6 \mathrm{kyr}$ within the interglacial and $2.3 \mathrm{kyr}$ for the early glacial (Table 2). Although our observation cannot rule out an initial forcing by precession harmonics, that can be modulated by sea-ice changes and may affect the timing of the millennial scale variability by producing non-stationary cycles throughout 
the MIS 19 (Ferretti et al., QSR, 2015), the observation that intra-interglacial events occur too often to be explained by a 5-6 kyr cyclicity, suggest that a precession forcing is likely not the cause of intrainterglacial events apparent in the Sulmona record.

Another significant periodicity of between ca. 4.2 and $3.5 \mathrm{kyr}$ is also evident (Fig. 9), but its intensity is also reduced during the MIS 19c, again suggesting that forcing of millennial and sub-millennial scale variability changed between interglacial and transitional periods.

\section{Conclusions}

In this work, we have presented a multiproxy record (high resolution stable carbon and oxygen isotope, low resolution elemental and mineralogical composition, and biogenic silica content) obtained from endogenic lacustrine sediments of the Sulmona Basin (central Italy). The record is anchored onto a fully independent time-scale based on ${ }^{40} \mathrm{Ar} /{ }^{39} \mathrm{Ar}$ dating of six tephra layers interbedded in the lacustrine sediment, and covers the ca. 790-770 ka period, thus encompassing the interglacial portion of Marine Isotope Stage MIS 19, or MIS 19c ( 788-777 ka). Hydrological and environmental proxies coherently indicate that the post-interglacial period is marked by major changes in climatic and environmental conditions. Within the MIS19c interglacial, a low-intensity, though significant, centennial- to millennialscale hydrological and environmental variability is present and shows a non-stationary pacing. In particular, a major event of rainfall reduction and environmental deterioration, $\sim 1 \mathrm{kyr}$ long, occurred at ca. $786 \mathrm{ka}$ according to our age model. Comparison of the Sulmona record with records from the Iberian margin (Sánchez-Goñi et al., 2016) and from the sub-polar North Atlantic (Kleiven et al., 2011), both reported on the radiometric Sulmona chronology through paleoclimatic alignment (sensu Govin et al., 2015) points to different mechanisms operating in different periods. Major dry events on land occurring 
540 after the end of the interglacial are associated with AMOC disruptions and increased iceberg discharge 541 in the sub-polar north Atlantic. Within the interglacial (ca. 788-777 ka), the event at ca. $786 \mathrm{ka}$ also 542 appears related to a lower intensity perturbation of the oceanic circulation. Other intra-interglacial events 543 are not so clearly associated with changes in marine proxies, though similarities with the sub-polar record 544 suggest a link between rainfall amount is southern Europe and deep hydrography in the northern North 545 Atlantic. We propose that changes in local convection, potentially related to feedbacks between 546 atmosphere and sea-ice, may have created unstable density stratification conditions, which may have 547 impacted the westerly circulation and the related moisture transport over the Mediterranean Basin. 548 Noteworthy, for MIS 19 as a whole, a higher global ice volume was proposed based on modelled global 549 sea level (Bintanja et al. 2005; Bintanja and van de Wal 2008). Possibly, this configuration would have 550 caused a more pronounced "glacial" character for the MIS 19c interglacial, with larger global ice volume 551 influencing dynamics and intensity of deep convection in the eastern North Atlantic, with downstream 552 influences on rainfall variability over southern Europe. This suggests that also small changes in boundary 553 conditions (and particularly of ice-volume and temperature) can strongly influence the millennial-scale 554 climate variability during interglacial periods.

\section{Acknowledgement}

557 This work has been developed in the frame of the project HELPING (Hydrological Evolution of Past 558 INterGlacial), funded by the National Geographic Society through an Early Career Grant assigned to E. 559 R (CP-073ER-17). It was also part of project PRA_2018_41 "Georisorse e Ambiente" funded by the 560 University of Pisa. ${ }^{40} \mathrm{Ar} /{ }^{39} \mathrm{Ar}$ dating was funded by the SYSTER program (INSU CNRS) assigned to S. $561 \mathrm{~N}$ (ChronoBM project). ER, GZ, RND and PCT were also supported by an Australian Research Council 562 Discovery Projects grant (DP160102969). PCT acknowledges funding from the UK Natural 
Environment Research Council (grant NE/ I025115/1). GZ, BG and GM acknowledges funding from MIUR-PRIN 2017 "Future" (leader GZ), The authors thank M.F. Sanchez-Goni, D. Hodell and T. Rodrigues for providing data for comparison, and acknowledge C. Gini, A. Chitula Moura and N. Vivoli 566 for help with XRPD and J. Krbanjevic with FTIRS sample preparation and data acquisition. Ola 567 Kwiecien and three other anonymous reviewers are acknowledged for their useful comments which 568 substantially improved the quality of the manuscript.

\section{References}

570 Alley, R. B., Mayewski, P. A., Sowers, T., Stuiver, M., Taylor, K. C., Clark, P. U. 1997. Holocene 571 climatic instability: A prominent, widespread event 8200 yr ago. Geology, 25(6), 483-486.

572 Alley, R. B., Ágústsdóttir, A. M. 2005. The 8k event: cause and consequences of a major Holocene abrupt 573 climate change. Quaternary Science Reviews, 24(10-11), 1123-1149.

574 Barber, D. C., Dyke, A., Hillaire-Marcel, C., Jennings, A. E., Andrews, J. T., Kerwin, M. W., Gagnon, 575 J. M. 1999. Forcing of the cold event of 8,200 years ago by catastrophic drainage of Laurentide lakes. $576 \quad$ Nature 400 (6742), 344.

577 Barbieri, M., Boschetti, T., Petitta, M., Tallini, M., 2005. Stable isotope $\left({ }^{2} \mathrm{H},{ }^{18} \mathrm{O}\right.$ and $\left.{ }^{87} \mathrm{Sr} /{ }^{86} \mathrm{Sr}\right)$ and 578 hydrochemistry monitoring for ground water hydrodynamics analyses in a karst aquifer (Gran Sasso, 579 Central Italy). Applied Geochemistry 20, 2063-2081.

580 Bard, E., Delaygue, G., Rostek, F., Antonioli, F., Silenzi, S., Schrag, D., 2002. Hydrological conditions 581 in the western Mediterranean basin during the deposition of Sapropel 6 ( $\sim 175 \mathrm{kyr})$. Earth and Planetary 582 Science Letters 202, 481-494. 
585 Bertini, A., Toti, F., Marino, M., Ciaranfi, N. 2015. Vegetation and climate across the Early-Middle 586 Pleistocene transition at Montalbano Jonico, southern Italy. Quaternary International 383, 74-88.

587 Bianchi, G. G., McCave, I. N. 2000. Hydrography and sedimentation under the deep western boundary 588 current on Björn and Gardar Drifts, Iceland Basin. Marine Geology 165(1-4), 137-169

589 Bintanja, R., van de Wal, R.S.W. 2008 North American ice-sheet dynamics and the onset of 100,000590 year glacial cycles. Nature 454, 869-872.

591 Bintanja, R., van de Wal, R.S.W., Oerlemans, J. 2005 Modelled atmospheric temperatures and global 592 sea levels over the past million years. Nature 437,125-128.

593 Blaauw, M., Christen, J. A. 2011. Flexible paleoclimate age-depth models using an autoregressive 594 gamma process. Bayesian analysis $6(3), 457-474$.

595 Boretto G., Zanchetta G., Ciulli A., Bini M., Fallick A.E., Lezzerini M., Colonense A.C., Zembo I., 596 Regattieri E., Sarti, G. 2017. Stratigraphy, pedological features, paleontology, geochemistry and 597 chronology of the "loess-like" deposits of the Buca dei Corvi Section (central Italy). Catena, 151225 $598 \quad 237-$

599 Cavinato, G. P., Miccadei, E. 2000. Pleistocene carbonate lacustrine deposits: Sulmona basin (central 600 Apennines, Italy). In: Gierlowsky-Kordesch, E.H., Kelts, K.R. (Eds.), Lake Basins Through Space and 601 Time. Studies in Geology, American Association of Petroleum Geologists, 46, 517-526. 
602 Clarke, G. K., Leverington, D. W., Teller, J. T., Dyke, A. S. 2004. Paleohydraulics of the last outburst 603 flood from glacial Lake Agassiz and the 8200 BP cold event. Quaternary Science Reviews 23(3-4), 389604407.

605 Coelho, A. A. 2018. TOPAS and TOPAS-Academic: an optimization program integrating computer 606 algebra and crystallographic objects written in C++. Journal of Applied Crystallography 51(1), 210-218.

607 Columbu, A., Drysdale, R., Capron, E., Woodhead, J., De Waele, J., Sanna, L., Bajo, P. 2017. Early last 608 glacial intra-interstadial climate variability recorded in a Sardinian speleothem. Quaternary Science 609 Reviews 169, 391-397.

610 Cullen, H. M., Kaplan, A., Arkin, P. A. 2002. Impact of the North Atlantic Oscillation on Middle Eastern 611 climate and streamflow. Climatic Change, 55(3), 315-338.

612 Cvetkoska, A., Levkov, Z., Reed, J.M., Wagner, B., Panagiotopoulos, K., Leng, M.J., Lacey, J.H., 2015. 613 Quaternary climate change and Heinrich events in the southern Balkans: Lake Prespa 614 diatompalaeolimnology from the last interglacial to present. J. Paleolimnol. 53 (2), 215-231.

615 D'Addabbo, M., Sulpizio, R., Guidi, M., Capitani, G., Mantecca, P., Zanchetta, G., 2015. Ash leachates 616 from some recent eruptions of Mount Etna (Italy) and Popocatépetl (Mexico) volcanoes and their impact 617 on amphibian living freshwater organisms. Biogeosciences 12, 7087-7106.

618 Desiderio, G., Rusi, S., Tatangelo, F., 2005a. Utilizzo di tecniche isotopiche $\left({ }^{18} \mathrm{O}\right.$ e $\left.{ }^{2} \mathrm{H}\right)$ nello studio delle 619 acque sotterranee in aree protette dell'Appennino Abruzzese. Rivista Italiana Agrometeorologia 9 (1), $62090-91$. 
621 Desiderio, G., Ferracuti, L., Rusi, S., Tatangelo, F., 2005b. Il contributo degli isotopi naturali ${ }^{18} \mathrm{O}$ e ${ }^{2} \mathrm{H}$ 622 nello studio delle idrostrutture carbonatiche abruzzesi e delle acque mineralizzate nell'area abruzzese e 623 molisana. Giornale Geologia Applicata 2, 453-458.

624 Drijfhout, S., Gleeson, E., Dijkstra, H. A., Livina, V. 2013. Spontaneous abrupt climate change due to 625 an atmospheric blocking-sea-ice-ocean feedback in an unforced climate model simulation. Proceedings 626 National Academy of Science. USA 110, 19713-19718.

627 Drysdale, R. N., Zanchetta, G., Hellstrom, J. C., Fallick, A. E., Zhao, J. X. 2005. Stalagmite evidence for 628 the onset of the Last Interglacial in southern Europe at 129 $\pm 1 \mathrm{ka}$. Geophysical Research Letters 32(24).

629 Drysdale, R.N., Zanchetta, G., Hellstrom, J.C., Fallick, A.E., McDonald, J., Cartwright, I. 2007. 630 Stalagmite evidence for the precise timing of North Atlantic cold events during the early last glacial. 631 Geology 35, 77-80.

632 Elderfield, H., Ferretti, P., Greaves, M., Crowhurst, S., McCave, I. N., Hodell, D. A., Piotrowski, A. M. 633 2012. Evolution of ocean temperature and ice volume through the mid-Pleistocene climate transition. $634 \quad$ Science 337 (6095), 704-709.

635 Falcone, R. A., Falgiani, A., Parisse, B., Petitta, M., Spizzico, M., Tallini, M. 2008. Chemical and 636 isotopic $\left(\delta^{18} \mathrm{O} \%\right.$, $\delta^{2} \mathrm{H} \%, \delta^{13} \mathrm{C} \%$, $\left.{ }^{222} \mathrm{Rn}\right)$ multi-tracing for groundwater conceptual model of carbonate 637 aquifer (Gran Sasso INFN underground laboratory-central Italy). Journal of Hydrology 357, 368-388.

638 Ferretti, P., Crowhurst, S. J., Naafs, B. D. A., Barbante, C. 2015. The Marine Isotope Stage 19 in the 639 mid-latitude North Atlantic Ocean: astronomical signature and intra-interglacial variability. Quaternary 640 Science Reviews 108, 95-110. 
641 Fletcher, W. J., Müller, U. C., Koutsodendris, A., Christanis, K., Pross, J. 2013. A centennial-scale record 642 of vegetation and climate variability from 312 to $240 \mathrm{ka}$ (Marine Isotope Stages $9 \mathrm{c}-\mathrm{a}, 8$ and $7 \mathrm{e}$ ) from 643 Tenaghi Philippon, NE Greece. Quaternary Science Reviews 78, 108-125.

644 Francke, A., Wagner, B., Just, J., Leicher, N., Gromig, R., Baumgarten, H., Vogel, H., Lacey, J.H., 645 Sadori, L., Wonik, T., Leng, M. J., Zanchetta, G., Sulpizio, R., Giaccio, B., 2016. Sedimentological 646 processes and environmental variability at Lake Ohrid (Macedonia, Albania) between $637 \mathrm{ka}$ and the 647 present. Biogeoscience, 13 (4),1179-1196.

648 Freytet, P., Verrecchia, E. P. 2002. Lacustrine and palustrine carbonate petrography: an overview. 649 Journal of Paleolimnology 27 (2), 221-237.

650 Galaasen, E. V., Ninnemann, U. S., Irvalı, N., Kleiven, H. K. F., Rosenthal, Y., Kissel, C., Hodell, D. 651 A. 2014. Rapid reductions in North Atlantic deep water during the peak of the last interglacial period. 652 Science 343(6175), 1129-1132.

653 Genty, D., Baker, A., Massault, M., Proctor, C., Gilmour, M., Pons-Branchu, E., Hamelin, B. 2001. Dead 654 carbon in stalagmites: carbonate bedrock paleodissolution vs. ageing of soil organic matter. Implications 655 for ${ }^{13} \mathrm{C}$ variations in speleothems. Geochimica et Cosmochimica Acta 65(20), 3443-3457.

656 Gemelli, M., D'Orazio, M., Folco, L. (2015). Chemical analysis of iron meteorites using a hand-held X657 ray fluorescence spectrometer. Geostandards and Geoanalytical Research 39(1), 55-69.

658 Giaccio, B., Messina, P., Sposato, A., Voltaggio, M., Zanchetta, G., Galadini, F., Gori, S., Santacroce, 659 R. 2009. Tephra layers from Holocene lake sediments of the Sulmona Basin, central Italy: implications 660 for volcanic activity in Peninsular Italy and tephrostratigraphy in the central Mediterranean area. 661 Quaternary Science Reviews 28 (25), 2710-2733. 
Giaccio, B., Nomade, N., Wulf, S., Isaia, R., Sottili, G., Cavuoto, G., Galli, P., Messina, P., Sposato, A., Sulpizio, R., Zanchetta, G., 2012. The late MIS 5 Mediterranean tephra markers: a reappraisal from peninsular Italy terrestrial records. Quaternary Science Reviews 56, 31-45.

Giaccio, B., Castorina, F., Nomade, S., Scardia, G., Voltaggio, M., Sagnotti, L., 2013. Revised chronology of the Sulmona lacustrine succession, central Italy. Journal of Quaternary Science 28, 545667551.

Giaccio, B., Regattieri, E., Zanchetta, G., Nomade, S., Renne, P. R., Sprain, C. J., Drysdale, R. N., Tzedakis, P. C., Messina, P., Scardia, G., Sposato, A., Bassinot, F. 2015. Duration and dynamics of the best orbital analogue to the present interglacial. Geology 43 (7), 603-606.

671 Giraudi, C., Zanchetta, G., Sulpizio, R. 2013. A Late-Pleistocene phase of Saharian dust deposition in 672 the high Apennine mountains (Italy). Alpine and Mediterranean Quaternary 26, 110-122.

673 Gottschalk, J., Skinner, L. C., Misra, S., Waelbroeck, C., Menviel, L., Timmermann, A. 2015. Abrupt 674 changes in the southern extent of North Atlantic Deep Water during Dansgaard-Oeschger events. Nature 675 Geoscience 8(12), 950-953.

676 Gouveia, C., Trigo, R. M., DaCamara, C. C., Libonati, R., \& Pereira, J. 2008. The North Atlantic 677 oscillation and European vegetation dynamics. International Journal of Climatology,28(14), 1835-1847.

678 Govin, A., Capron, E., Tzedakis, P. C., Verheyden, S., Ghaleb, B., Hillaire-Marcel, C., Blunier, T. 2015. 679 Sequence of events from the onset to the demise of the Last Interglacial: Evaluating strengths and 680 limitations of chronologies used in climatic archives. Quaternary Science Reviews 129, 1-36.

681 Head, M. J., Pillans, B., Farquhar, S. A. 2008. The Early-Middle Pleistocene transition: characterization 682 and proposed guide for the defining boundary. Episodes 31(2), 255. 
Jones, B. F., Bowser, C. J. 1978. The mineralogy and related chemistry of lake sediments. In Lakes (pp. 179-235). Springer, New York, NY.

Kim, S.T., O'Neil, J.R., 1997. Equilibrium and nonequilibrium oxygen isotope effects in synthetic 686 carbonates. Geochimica and Cosmochimica Acta 61 (16), 3461-3475.

687 Kleiven, H. F., Jansen, E., Curry, W. B., Hodell, D. A., Venz, K. 2003. Atlantic Ocean thermohaline 688 circulation changes on orbital to suborbital timescales during the mid-Pleistocene. Paleoceanography $68918(1)$.

690 Kleiven, H. K. F., Hall, I. R., McCave, I. N., Knorr, G., Jansen, E. 2011. Coupled deep-water flow and 691 climate variability in the middle Pleistocene North Atlantic. Geology 39(4), 343-346.

692 Kleppin, S., Jochum, M., Otto-Bliesner, B., Shields, C. A., Yeager, S. 2015. Stochastic atmospheric 693 forcing as a cause of Greenland climate transitions. Journal of Climatology 28, 7741-7763.

694 Knorr, G., and Lohmann, G., 2007, Rapid transitions in the Atlantic thermohaline circulation triggered 695 by global warming and meltwater during the last deglaciation: Geochemistry Geophysics Geosystems 8 , $696 \quad 1-22$.

697 Koutsodendris, A., Pross, J., Müller, U. C., Brauer, A., Fletcher, W. J., Kühl, N., Kitilova, E., Verhagen, 698 F.T.M., Lücke, A., Lotter, A. F. 2012. A short-term climate oscillation during the Holsteinian interglacial 699 (MIS 11c): An analogy to the 8.2 ka climatic event?. Global and Planetary Change 92, 224-235.

700 Leng, M. J., Marshall, J. D. 2004. Palaeoclimate interpretation of stable isotope data from lake sediment 701 archives. Quaternary Science Reviews 23, 811-831.

702 Lionello, P., Malanotte-Rizzoli, P., Boscolo, R. (Eds.). 2006. Mediterranean climate variability (Vol. 4). 703 Elsevier. 
Lisiecki, L. E., Raymo, M. E. 2005. A Pliocene-Pleistocene stack of 57 globally distributed benthic $\delta^{18} \mathrm{O}$ records. Paleoceanography 20(1).

López-Moreno, J. I., Vicente-Serrano, S. M., Morán-Tejeda, E., Lorenzo-Lacruz, J., Kenawy, A., Beniston, M. 2011. Effects of the North Atlantic Oscillation (NAO) on combined temperature and precipitation winter modes in the Mediterranean mountains: observed relationships and projections for the 21st century. Global and Planetary Change 77(1-2), 62-76.

Lüthi, D., Le Floch, M., Bereiter, B., Blunier, T., Barnola, J. M., Siegenthaler, U., Raynaud, D., Jouzel, J., Fischer, H., Kawamura, K., Stocker, T. F. 2008. High-resolution carbon dioxide concentration record 650,000-800,000 years before present. Nature 453(7193), 379.

Maegakiuchi, K., Hyodo, M., Kitaba, I., Hirose, K., Katoh, S., Sato, H. 2016. Brief sea-level fall event and centennial to millennial sea-level variations during Marine Isotope Stage 19 in Osaka Bay, Japan. Journal of Quaternary Science 31(7), 809-822.

Maiorano, P., Bertini, A., Capolongo, D., Eramo, G., Gallicchio, S., Girone, A., Pinto, P., Toti, F., Ventruti, G., Marino, M. 2016. Climate signatures through Marine Isotope Stage 19 in the Montalbano Jonico section (Southern Italy): A land-sea perspective. Palaeogeography, Palaeoclimatology, Palaeoecology 461, 341-361.

Mark, D. F., Renne, P. R., Dymock, R. C., Smith, V. C., Simon, J. I., Morgan, L. E., Staff, R.A., Ellis, B.S., Pearce, N. J. 2017. High-precision 40Ar/39Ar dating of Pleistocene tuffs and temporal anchoring of the Matuyama-Brunhes boundary. Quaternary Geochronology 39, 1-23.

Margari, V., Gibbard, P. L., Bryant, C. L., Tzedakis, P. C. (2009). Character of vegetational and environmental changes in southern Europe during the last glacial period; evidence from Lesvos Island, Greece. Quaternary Science Reviews, 28(13-14), 1317-1339. 
Marino, M., Bertini, A., Ciaranfi, N., Aiello, G., Barra, D., Gallicchio, S., Girone, A., La Perna, R., Lirer, 727 F., Maiorano, P., Petrosino, Toti, F. 2015. Paleoenvironmental and climatostratigraphic insights for 728 Marine Isotope Stage 19 (Pleistocene) at the Montalbano Jonico succession, south Italy. Quaternary 729 International 383, 104-115.

730 Marino, G., Rohling, E. J., Rodríguez-Sanz, L., Grant, K. M., Heslop, D., Roberts, A. P., Stanford, J.D., 731 Yu, J. (2015). Bipolar seesaw control on last interglacial sea level. Nature, 522(7555), 197.

732 McCave, I. N., Hall, I. R., 2006, Size sorting in marine muds: Processes, pitfalls, and prospects for 733 paleoflow-speed proxies: Geochemistry Geophysics Geosystems, v. 7,

734 McManus, J. F., Oppo, D. W., Cullen, J. L. (1999). A 0.5-million-year record of millennial-scale climate 735 variability in the North Atlantic. science, 283(5404), 971-975.

736 Meyer-Jacob, C., Vogel, H., Boxberg, F., Rosén, P., Weber, M. E., Bindler, R. 2014. Independent 737 measurement of biogenic silica in sediments by FTIR spectroscopy and PLS regression. Journal of 738 Paleolimnology, 52, 245-255.

739 Narcisi, B., 2000. Late Quaternary eolian deposition in central Italy. Quaternary Research 54 (2), 246$740 \quad 252$.

741 Nicholl, J. A., Hodell, D. A., Naafs, B. D. A., Hillaire-Marcel, C., Channell, J. E., Romero, O. E. 2012. 742 A Laurentide outburst flooding event during the last interglacial period. Nature Geoscience, 5(12), 901.

743 Niespolo, E. M., Rutte, D., Deino, A. L., Renne, P. R. 2017. Intercalibration and age of the Alder Creek 744 sanidine ${ }^{40} \mathrm{Ar} /{ }^{39} \mathrm{Ar}$ standard. Quaternary Geochronology 39, 205-213.

745 Nomade S., Bassinot, F., Marino, M., Simon, Q., Dewilde, F., Maiorano, P., Isguder, G., Blamart,D., 746 Girone, A., Scao, V., Pereira, A., Toti, F., Bertini, A., Combourieu-Nebout, N., Peral, C., Bourlès, D. 
L., Petrosino, P., Gallicchio S., and Ciaranfi, N. 2019. High-resolution foraminifer stable isotope record of MIS 19 at Montalbano Jonico, southern Italy: a window into Mediterranean climatic variability during 749 a low-eccentricity interglacial. Quaternary Science Reviews 205, 106-125.

750 Oliveira, D., Desprat, S., Yin, Q., Naughton, F., Trigo, R., Rodrigues, T., Abrantes, F., Sánchez-Goñi, 751 M. F. 2017. Unravelling the forcings controlling the vegetation and climate of the best orbital analogues 752 for the present interglacial in SW Europe. Climate Dynamics 51, 1-20.

753 Oppo, D. W., Lehman, S. J. 1993. Mid-depth circulation of the subpolar north Atlantic during the last 754 glacial maximum: Science 259, 1148-1152

755 Pol, K., Masson-Delmotte, V., Johnsen, S., Bigler, M., Cattani, O., Durand, G., Falourd, S., Jouzel J., 756 Minster B., Parrenin, F., Ritz, C., Steen-Larsen, H. C., Stenni, B. 2010. New MIS 19 EPICA Dome C 757 high-resolution deuterium data: hints for a problematic preservation of climate variability in the "oldest 758 ice”. Earth Planetary Science Letters 298, 95-103.

759 Quézel, P. 2002. Réflexions sur l'évolution de la flore et de la végétation au Maghreb méditerranéen 760 (Vol. 1). Paris: Ibis Press 112p.

761 Reale, M., Lionello, P. 2013. Synoptic climatology of winter intense precipitation events along the 762 Mediterranean coasts. Natural Hazards and Earth System Sciences 13(7), 1707-1722.

763 Renne, P. R., Mundil, R., Balco, G., Min, K., Ludwig, K. R. 2010. Joint determination of ${ }^{40}$ K decay 764 constants and $40 \mathrm{Ar} * / 40 \mathrm{~K}$ for the Fish Canyon sanidine standard, and improved accuracy for ${ }^{40} \mathrm{Ar} /{ }^{39} \mathrm{Ar}$ 765 geochronology. Geochimica et Cosmochimica Acta 74 (18), 5349-5367. 
Regattieri, E., Zanchetta, G., Drysdale, R. N., Isola, I., Hellstrom, J. C., Roncioni, A. 2014. A continuous stable isotope record from the penultimate glacial maximum to the Last Interglacial (159-121 ka) from Tana Che Urla Cave (Apuan Alps, central Italy). Quaternary Research 82(2), 450-461.

Regattieri, E., Giaccio, B., Zanchetta, G., Drysdale, R. N., Galli, P., Nomade, S., Peronace, E., Wulf, S., 2015. Hydrological variability over the Apennines during the Early Last Glacial precession minimum, as revealed by a stable isotope record from Sulmona Basin, Central Italy. Journal of Quaternary Science $30,19-31$

Regattieri, E., Giaccio, B., Galli, P., Nomade, S., Peronace, E., Messina P., Sposato, A., Boschi, C., Gemelli, M. 2016. A multi-proxy record of MIS 11-12 deglaciation and glacial MIS 12 instability from the Sulmona Basin (central Italy). Quaternary Science Reviews 32, 129-145.

Regattieri, E., Giaccio, B., Nomade, S., Francke, A., Vogel, H., Drysdale, R. N., Perchiazzi, N., Wagner, B., Gemelli, M., Mazzini, I., Boschi, C. Galli, P., Peronace, E. 2017. A Last Interglacial record of environmental changes from the Sulmona Basin (central Italy). Palaeogeography, Palaeoclimatology, Palaeoecology 472, 51-66.

Regattieri, E., Zanchetta, G., Isola, I., Bajo, P., Boschi, C., Perchiazzi, N., Drysdale, R. N., Boschi, C., Hellstrom, J. C., Francke, A., Wagner, B. 2018. A MIS 9/MIS 8 speleothem record of hydrological variability from Macedonia (FYROM). Global and Planetary Change 162, 39-52.

Regattieri, E., Isola, I., Zanchetta, G., Tognarelli, A., Hellstrom, J.C., Drysdale R.N., Boschi, C., Milevski, I., Temovski, M. 2019 Middle Holocene climate variability from a stalagmite from Alilica Cave (Southern Balkans). Alpine and Mediterranean Quaternary 32 (1) 2019, 1-16

Roberts, N., Jones, M. D., Benkaddur, A., Eastwood, W. J., Filippi, M. L., Frogley, M. R., Lamb, H. F., Leng, M. J., Reed, J. M., Stein, M., Stevens, L., Valero-Garces, B., Zanchetta, G., 2008. Stable isotope 
records of Late Quaternary climate and hydrology from Mediterranean lakes: the ISOMED synthesis. Quaternary Science Reviews 27, 2426-2441.

Sagnotti, L., Scardia, G., Giaccio, B., Liddicoat, J. C., Nomade, S., Renne, P. R., Sprain, C. J., 2014. 791 Extremely rapid directional change during Matuyama-Brunhes geomagnetic polarity reversal. 792 Geophysical Journal International 199, 1110-1124.

793 Sagnotti, L., Giaccio, B., Liddicoat, J. C., Nomade, S., Renne, P. R., Scardia, G., Sprain, C. J. 2016. How 794 fast was the Matuyama-Brunhes geomagnetic reversal? A new subcentennial record from the Sulmona 795 Basin, central Italy. Geophysical Journal International 204 (2), 798-812.

Sánchez-Goñi, M. F., Rodrigues, T., Hodell, D. A., Polanco-Martinez, J. M., Alonso-García, M., 797 Hernández-Almeida, I., Desprat, S., Ferretti, P. 2016. Tropically-driven climate shifts in southwestern 798 Europe during MIS 19, a low eccentricity interglacial. Earth and Planetary Science Letters 448, 81-93.

799 Schmidt, M.W., Spero, H. J., Lea, D.W., 2004, Links between salinity variation in the Caribbean and 800 North Atlantic thermohaline circulation. Nature 428, 160-163.

801 Sinopoli, G., Masi, A., Regattieri, E., Wagner, B., Francke, A., Peyron, O., Sadori, L. 2018. Palynology 802 of the Last Interglacial Complex at Lake Ohrid: palaeoenvironmental and palaeoclimatic inferences. 803 Quaternary Science Reviews 180, 177-192.

804 Smith, A. C., Wynn, P. M., Barker, P. A., Leng, M. J., Noble, S. R., Tych, W. 2016. North Atlantic 805 forcing of moisture delivery to Europe throughout the Holocene. Scientific reports, 6, 24745.

806 Talbot, M. R., Kelts, K. 1990. Paleolimnological Signatures from Carbon and Oxygen Isotopic Ratios in 807 Carbonates, from Organic Carbon-Rich Lacustrine Sediments: Chapter 6. In Lacustrine Basin 808 Exploration: Case Studies and Modern Analogs. Eds by Katz, B.J., publisher AAPG 
809 Tognarelli, A., Zanchetta, G., Regattieri, E., Isola, I., Drysdale, R. N., Bini, M., Hellstrom, J. C. 2018 a. 810 Wavelet analysis of $\delta^{18} \mathrm{O}$ and $\delta^{13} \mathrm{C}$ time-series from a Holocene speleothem record from Corchia Cave 811 (central Italy): insights for the recurrence of dry-wet periods in the Central Mediterranean. Italian Journal 812 of Geosciences 137(1), 128-137.

813 Tognarelli, A. 2018. The Use of Continuous Wavelet Transform for Ground-Roll Attenuation. In 80th 814 EAGE Conference and Exhibition 2018.

815 Tzedakis, P. C., Raynaud, D., McManus, J. F., Berger, A., Brovkin, V., Kiefer, T. 2009. Interglacial 816 diversity. Nature Geoscience, 2(11), 751.

817 Tzedakis, P. C. 2010. The MIS 11 - MIS 1 analogy, southern European vegetation, atmospheric methane 818 and the "early anthropogenic hypothesis". Climate of the Past, 6, 131-144.

819 Tzedakis, P.C., Channell, J. E. T., Hodell, D. A., Kleiven, H. F. Skinner, L. C. 2012. Determining the 820 natural length of the current interglacial. Nature Geoscience, 5, 138-141.

821 Tzedakis, P.C., Drysdale, R.N., Margari, V., Skiner, L., Menviel, L., Rhodes, R.H., Taschetto, A.S., 822 Hodell, D.A., Crowhurst, S.J., Hellstrom, J.C., Fallick, A.E., Grimalt, J.O., McManus, J.F., Martrat, B., 823 Mokeddem, Z., Parrenin, F., Regattieri, E., Roe, K., Zanchetta, G. 2018 Enhanced climate instability in 824 the North Atlantic and southern Europe during the Last Interglacial. Nature Communications accepted, 825 DOI: $10.1038 / \mathrm{s} 41467-018-06683-3$

826 Tzedakis, P. C., Frogley, M. R., Lawson, I. T., Preece, R. C., Cacho, I. de Abreu, L. 2004. Ecological 827 thresholds and patterns of millennial-scale climate variability: The response of vegetation in Greece 828 during the last glacial period. Geology 32 109-112. 

of the Mediterranean: synoptic patterns, temperature, precipitation, winds, and their extremes. In: The

831 Climate of the Mediterranean Region-From the Past to the Future. Elsevier

832 Vogel, H., Rosén, P., Wagner, B., Melles, M., Persson, P. 2008. Fourier transform infrared spectroscopy, 833 a new cost-effective tool for quantitative analysis of biogeochemical properties in long sediment records. 834 Journal of Paleolimnology 40 (2), 689-702.

835 Vogel, H., Wagner, B., Zanchetta, G., Sulpizio, R., Rosén, P., 2010. A paleoclimatic record with 836 tephrochronological age control for the last glacial-interglacial cycle from Lake Ohrid, Albania and 837 Macedonia. Journal of Paleolimnology 44, 295-310.

838 Vogel, H., Meyer-Jacob, C., Thöle, L., Lippold, J. A., Jaccard, S. L. 2016. Quantification of biogenic 839 silica by means of Fourier transform infrared spectroscopy (FTIRS) in marine sediments. Limnology and 840 oceanography: methods $14(12), 828-838$.

841 Yin, Q. Z., Berger, A. 2012. Individual contribution of insolation and $\mathrm{CO}_{2}$ to the interglacial climates of 842 the past 800,000 years. Climate Dynamics 38(3-4), 709-724.

843 Yin, Q. Z., Berger, A. 2010. Insolation and CO 2 contribution to the interglacial climate before and after 844 the Mid-Brunhes Event. Nature Geoscience 3(4), 243.

845 Xoplaki, E., Gonzalez-Rouco, J. F., Luterbacher, J., Wanner, H., 2003. Mediterranean summer air 846 temperature variability and its connection to the large-scale atmospheric circulation and SSTs. Climate 847 Dynamics $20(7-8), 723-739$.

848 Weirauch, D., Billups, K., Martin, P. 2008. Evolution of millennial-scale climate variability during the 849 mid-Pleistocene. Paleoceanography, 23(3). 

2015. Lateglacial and early Holocene climates of the Atlantic margins of Europe: Stable isotope, mollusc and pollen records from Orkney, Scotland. Quaternary Science Reviews 122, 112-130.

Zanchetta, G., Drysdale, R. N., Hellstrom, J. C., Fallick, A. E., Isola, I., Gagan, M. K., Pareschi, M. T. 2007. Enhanced rainfall in the Western Mediterranean during deposition of sapropel S1: stalagmite evidence from Corchia cave (Central Italy). Quaternary Science Reviews 26(3-4), 279-286.

Zanchetta, G., van Welden, A., Baneschi, I., Drysdale, R.N., Sadori, L., Roberts, N., Giardini, G., Beck, C., Pascucci, V., Sulpizio, R. 2012. Multiproxy record for the last 4500 years from Lake Shkodra (Albania/Montenegro). Journal of Quaternary Sciences,27, 780-789.

Zanchetta G., Regattieri E., Giaccio B., Wagner B., Sulpizio R., Francke A., Vogel L.H., Sadori L., Masi

Zanchetta, G., Bini, M., Giaccio, B., Manganelli, G., Benocci, A., Regattieri, E., Colonese, A. C., Boschi, Mediterranean derived from terrestrial molluscs and carbonate stable isotopes from Sulmona Basin (Italy). Palaeogeography, Palaeoclimatology, Palaeoecology 485, 236-246.

867 Zanchetta, G., Baneschi, I., Francke, A., Boschi, C., Regattieri, E., Wagner, B., Lacey, J.H., Leng, M., 868 Vogel, H., Sadori, L. 2018. Evidence for carbon cycling in a large freshwater lake in the Balkans over 869 the last 0.5 million years using the isotopic composition of bulk organic matter. Quaternary Science 870 Review, 202, 154-165. 
875 Table 1- Names, ages, uncertainties and depths of tephra layers used in the age-depth modelling 876 procedure. Grey cells indicate tephra occurring within the interval discussed here. *Age from Giaccio 877 et al. (2015); ** age from this study.

878 Table 2- - Age, length and pacing for events of reduced precipitation as from the Sulmona record. Roman 879 numbers are as in Figs. 3, 7 and 9; events reported in italics are from the low-resolution series from 880 Giaccio et al. (2015).

881 Figure 1- a) Location of the Sulmona Basin and of other sites mentioned in the text; b) Schematic 882 stratigraphy of the composite SUL6 lacustrine unit; c) Simplified morpho-stratigraphic scheme of the 883 Sulmona sedimentary succession.

884 Figure 2-Left panel: tephra position and labelling (see Table 1) and Bacon age model for the discussed 885 interval. The red line represents the proposed age-depth relationship, light-green lines represent $95 \%$ 886 confidence intervals. The interval highlighted in yellow represents the interval analyzed in the present 887 work. Right panel: Age probability density spectrum for the SUL2-19 tephra. Blue and grey bars are the 888 individual ages ( $2 \sigma$ error) included and not included in the weighted mean age calculation, respectively. 889 ACs value is from Niespolo et al., 2017.

890 Figure 3- Sulmona proxy time series presented in this work. A) and B) stable oxygen and carbon isotope 891 composition of bulk lacustrine calcite $\left(\delta^{18} \mathrm{O}\right.$ and $\delta^{13} \mathrm{C}$ composition), on A) the lower resolution $\delta 18 \mathrm{O}$ 892 series from Giaccio et al. (2015) is shown as well (light blue line); C) Calcium content (XRF 
counting*sec); D) Biogenic silica content (\% wt); E) Ratio of peak areas of quartz and calcite XRD analyses. Grey shadings indicate events of reduced precipitation, roman numbers are as in Table 2.

Figure 4- Correlation plots of $\delta^{13} \mathrm{C}$ and $\delta^{18} \mathrm{O}$ composition

Figure 5- Tuning of the U1385 pollen record (with the published chronology by Sánchez-Goñi et al., 2016) on the Sulmona $\delta^{18} \mathrm{O}$ time series (this study). Red circles indicate points used for alignment. Yellow shadings indicate the events of forest contraction identified by Sanchez-Goni et al., (2016) as well as the Tajo interglacial as apparent from the same record. Grey shadings are events of reduced precipitation as defined in Fig. 3 and Table 2. Dotted grey lines indicate proposed correlations between Sulmona and U1385 events.

Figure 6- Comparison between Sulmona $\delta^{18} \mathrm{O}$ (a, light line is the lower resolution series from Giaccio et al. (2015) and the U1385 record (Sánchez-Goñi et al., 2016) on the Sulmona chronology; b) U1385 Mediterranean forest pollen percentage; c) U1385 planktonic $\delta^{18} \mathrm{O}$; d) U1385 benthic $\delta^{13} \mathrm{C}$; e) U1385

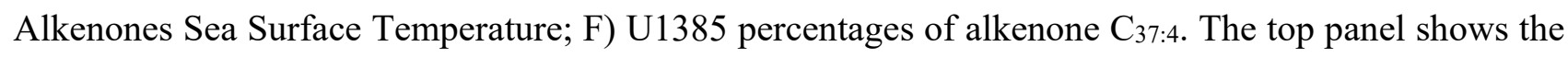
U1385 benthic $\delta^{18} \mathrm{O}$ record and MI stages and substages division. Roman numbers indicate the events of reduced precipitation from the Sulmona record (see Table 2). Grey rectangles are as from Table 2 and Fig. 3 and indicates events of reduced precipitation in the Sulmona basin.

Figure 7- Upper panel: tuning of the IRD record from core ODP-983 (Light-blue solid plot, on the original chronology by Kleiven et al., 2010) on Sulmona $\delta^{18} \mathrm{O}$ time series (this study and Giaccio et al., 2015). Red circles indicate selected alignment points. Lower panel: comparison of U1385 (green, planktonic $\delta^{18} \mathrm{O} \%$ and $\mathrm{C} 37: 4$ based freshwater index) and ODP-983 (blue, planktonic and IRD) records, both reported on the Sulmona chronology. Grey rectangles indicate the intervals of IRD deposition in the North Atlantic. 
915 Figure 8- Comparison between Sulmona $\delta^{18} \mathrm{O}$ and the ODP-983 record (Kleiven et al., 2011) reported 916 on the Sulmona chronology; b) ODP-938 Sortable silt percentage; c) ODP-983 planktonic $\delta^{18} \mathrm{O}$; d) ODP917983 benthic $\delta^{13} \mathrm{C}$; Roman numbers and grey rectangles indicate the events of reduced precipitation from 918 the Sulmona record and are as shown in Table 2 and Figure 3.

919 Figure 9- Lower panel: Sulmona oxygen isotope real wavelet spectrum. The lower black line indicates 920 the cone of influence. It delimits the spectrum in two regions, where the portion below the black line may 921 be affected by edge effects and thus shows frequencies that are not significant considering the total length 922 of the record (Tognarelli et al., 2018b). The contour delimited by the black line encloses the area with a 923 confidence greater than 95\%. Upper panel: the series reconstructed considering 5-6 and 4.2-4.5 kyr 924 periodicities.

926 Figure S1-FESEM images of Sulmona lacustrine sediment.

927 

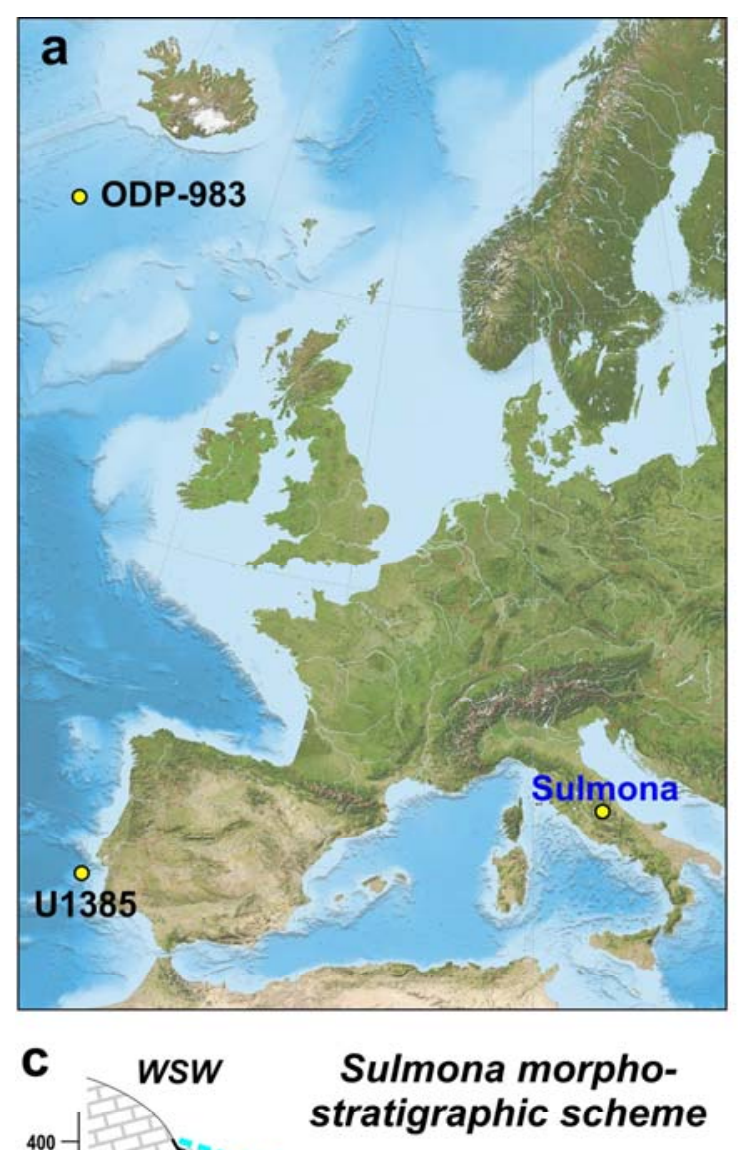
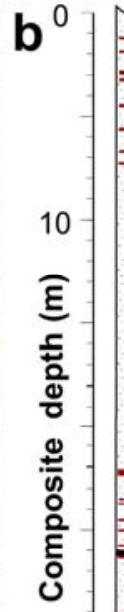

30

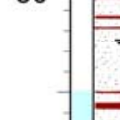

40

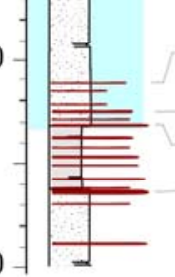

$50-$

Lithofacies

7 Lacustrine whitish calcareous mud
Composite SUL6 unit (MIS 20-MIS 17)

Tephra ${ }^{40} \mathrm{Ar} /{ }^{39} \mathrm{Ar}$ age

$(k a \pm 2 \sigma)$

ACs-2 at $1.1891 \mathrm{Ma}$

(Niespolo et al., 2017)

SUL $2-1 \quad 715.9 \pm 5.4^{*}$

SUL 2-7 $\quad 747.4 \pm 2.6$

Giaccio et al. (2013)

Giaccio et al. (2015)

SUL 2-10 $752.6 \pm 1.7$

Giaccio et al. (2015)

SUL 2-15 $770.9 \pm 1.6$

Sagnotti et al. (2014)

SUL 2-16 $779.6 \pm 2.0$

Sagnotti et al. (2014) Giaccio et al. (2015)

SUL 2-19 $784.7 \pm 2.4 \quad$ This study

SUL 2-22 $789.3 \pm 1.9$

SUL 2-29 $805.2 \pm 2.3$

Sagnotti et al. (2014)

Giaccio et al. (2013) Giaccio et al. (2015)

${ }^{*} 719.6 \pm 1.6$, redetermined

Peat

Peat
Tephra

Investigated Lacustrine gray
silty-clay

b SUL5 (a - MIS 11-MIS 10; b - MIS 13-MIS12)

Vico $\beta$ c. 412 ka

450-

$250-$

$\sim 500 \mathrm{~m}$

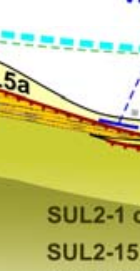

ín

Albano 7 c. 36 ka

C22 c. 94 ka

X-5/X-6 c. 106 ka/109 ka
Pozzolane Rosse c. 457

SC1. C. 330-320 $\quad$ X-5/X-6 c. 106 ka/109 ka
Pozzolane Rosse c. 457 ka

TBA c. 527 ka

SUL6b $2905 \mathrm{ka}-$ c. 805 SUL2-15 c. $771 \mathrm{ka}$

SUL4-3 (MIS 5-MIS 3 )

Mesozoic limestone

Present floodplain

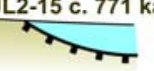

E. SUL5c Pedo-alluvial complex (MIS 16-MIS 12)

$\mathrm{d}={ }_{c}^{\mathrm{a}}$ Main tephras in SUL4-3 (a) SUL5a (b), SUL5b (c) and SUL6 (d) units

a Unconformity (a - paleosol; b - fluvial incision)

Aa SUL6 (a - MIS 17-MIS 16; b - MIS 20-MIS 18)

.... b Depositional (a) and erosional (b) terrace and elevation range ( $m$ a.s.l.)

Figure 1 

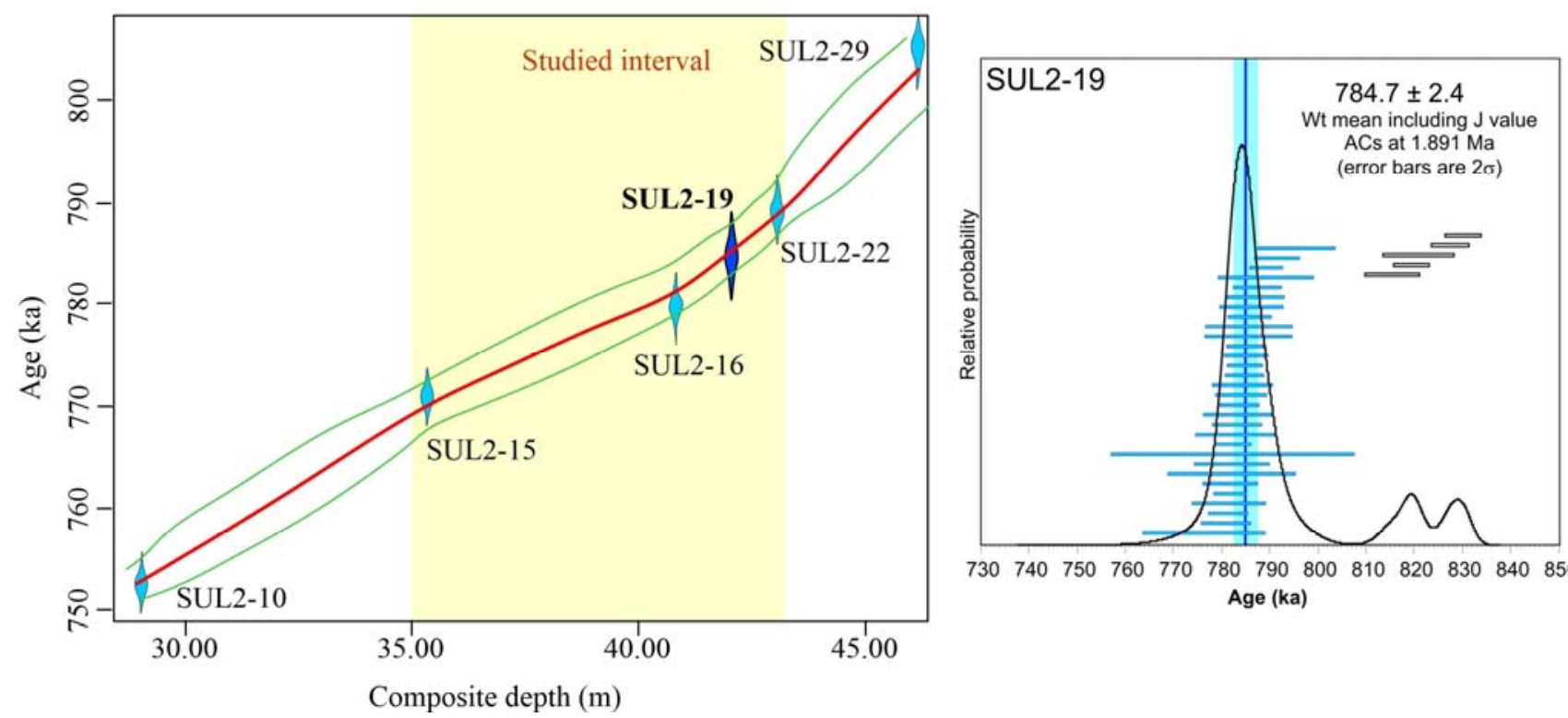

$\begin{array}{lllllllllllll}730 & 740 & 750 & 760 & 770 & 780 & 790 & 800 & 810 & 820 & 830 & 840 & 85\end{array}$ Age (ka)

930

Figure 2 


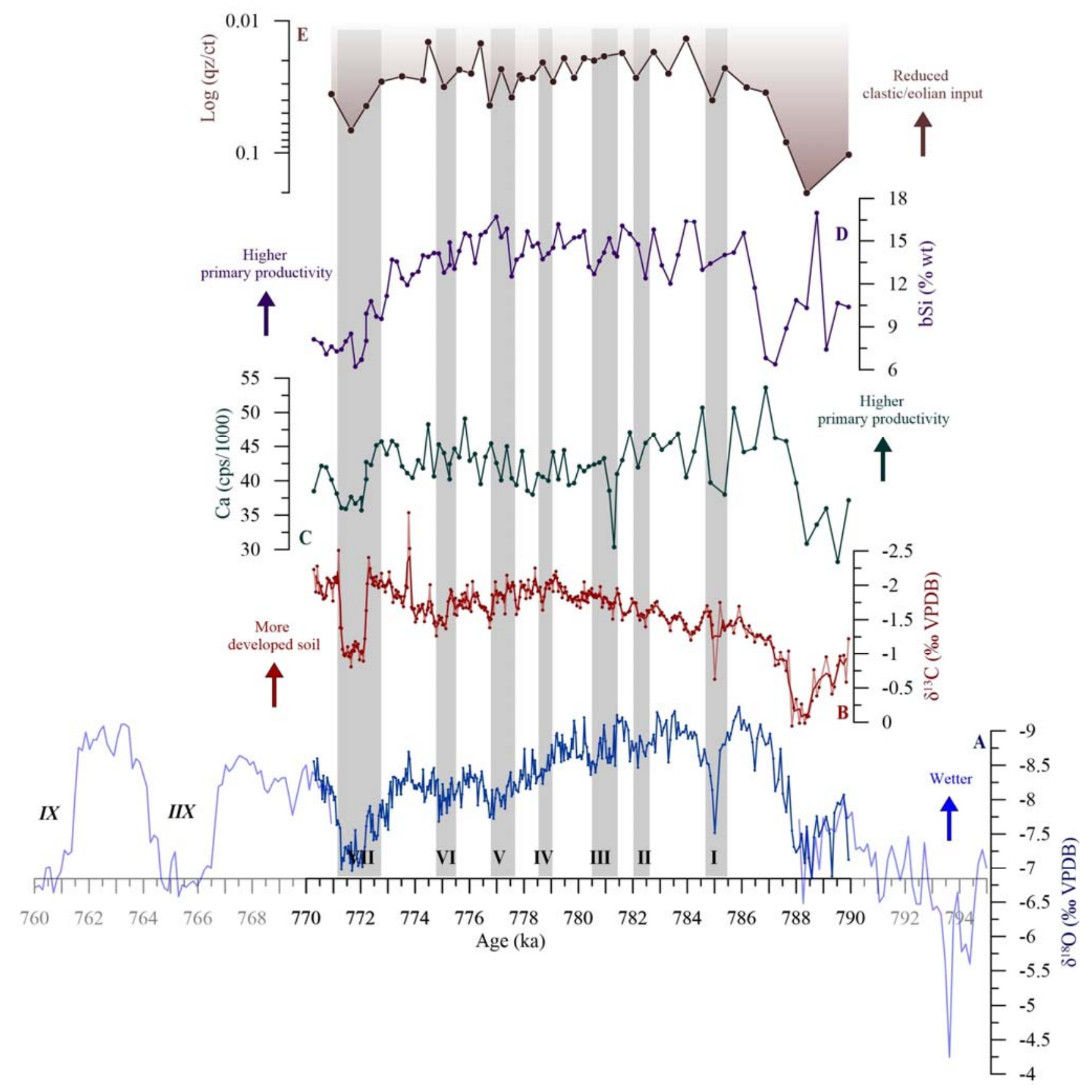




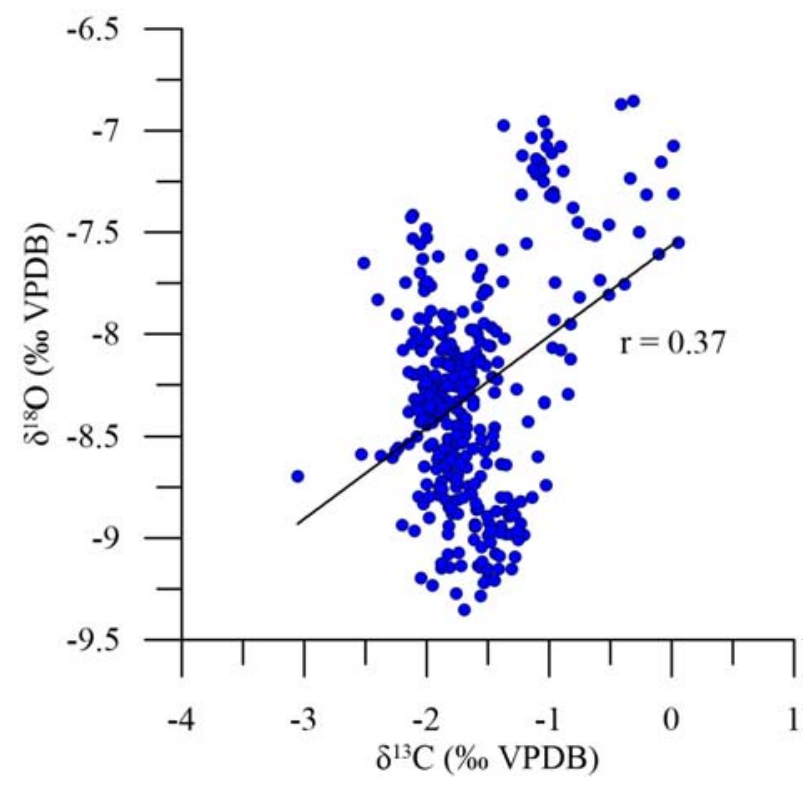

933

Figure 4

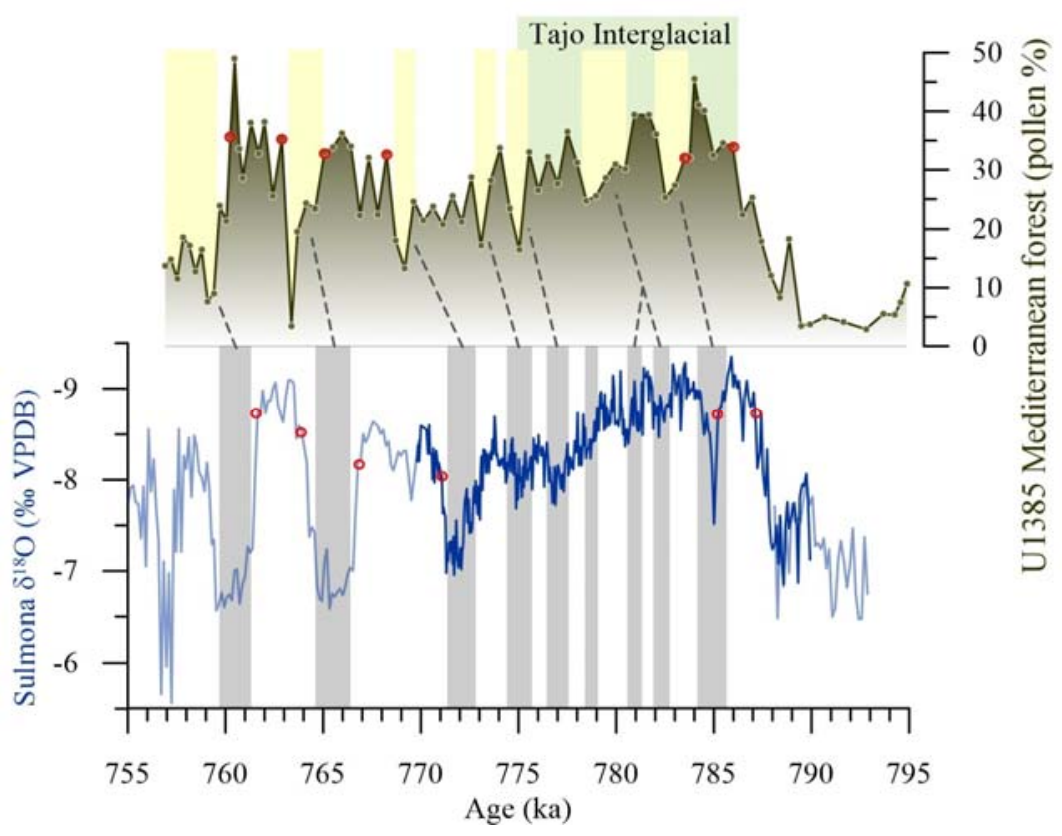

935

$936 \quad$ Figure 5 


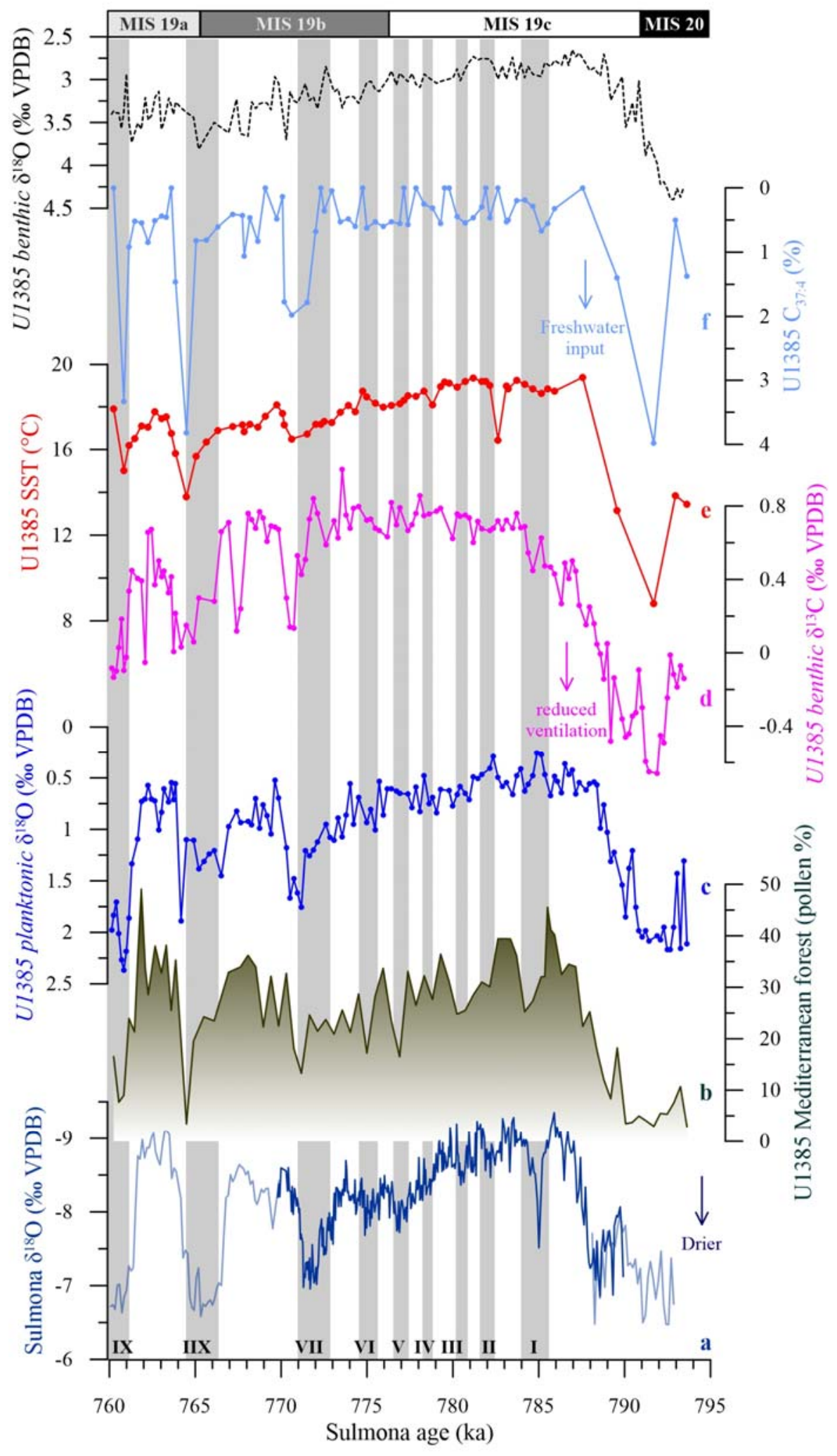


Figure 6
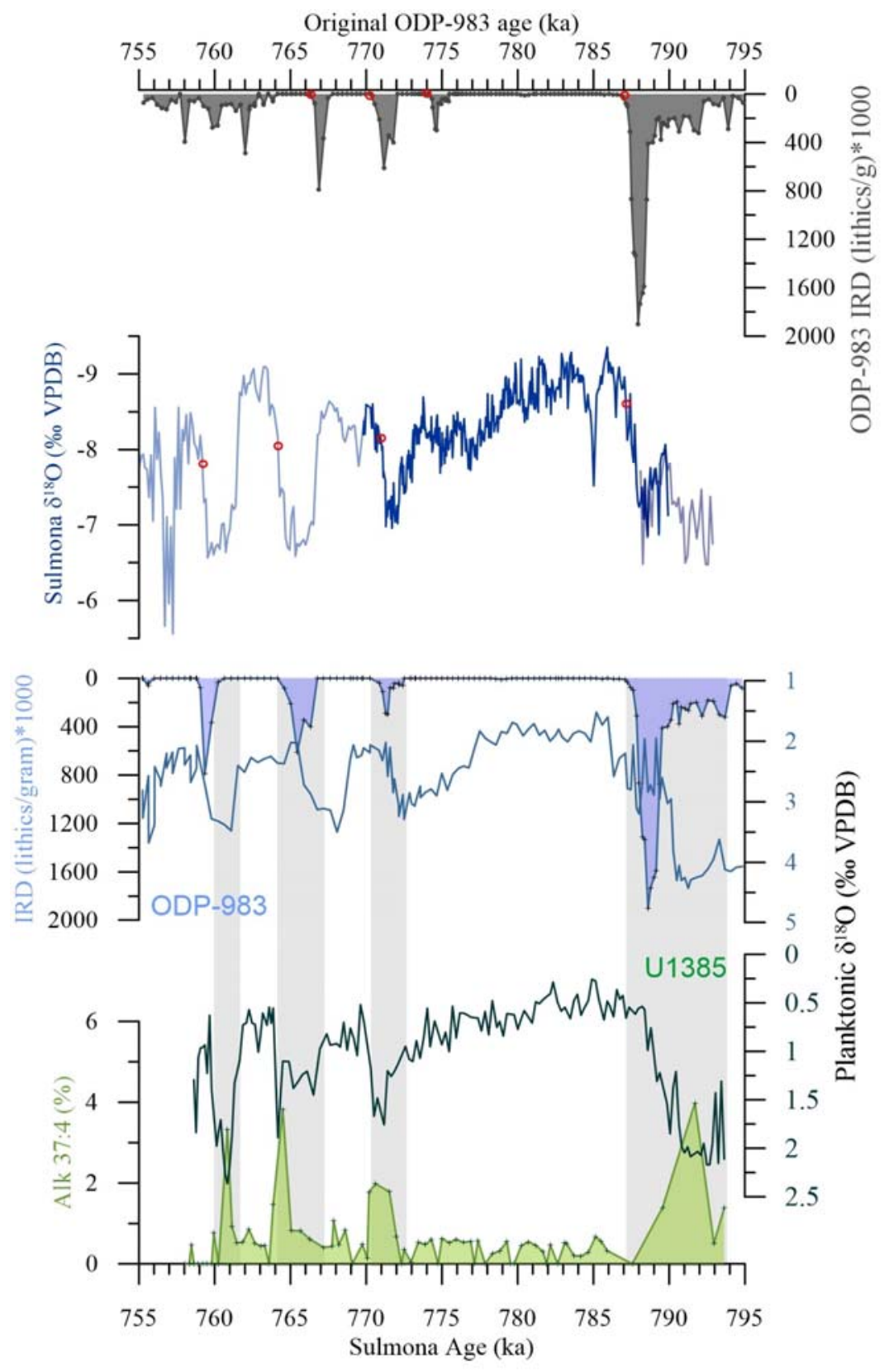

Figure 7 


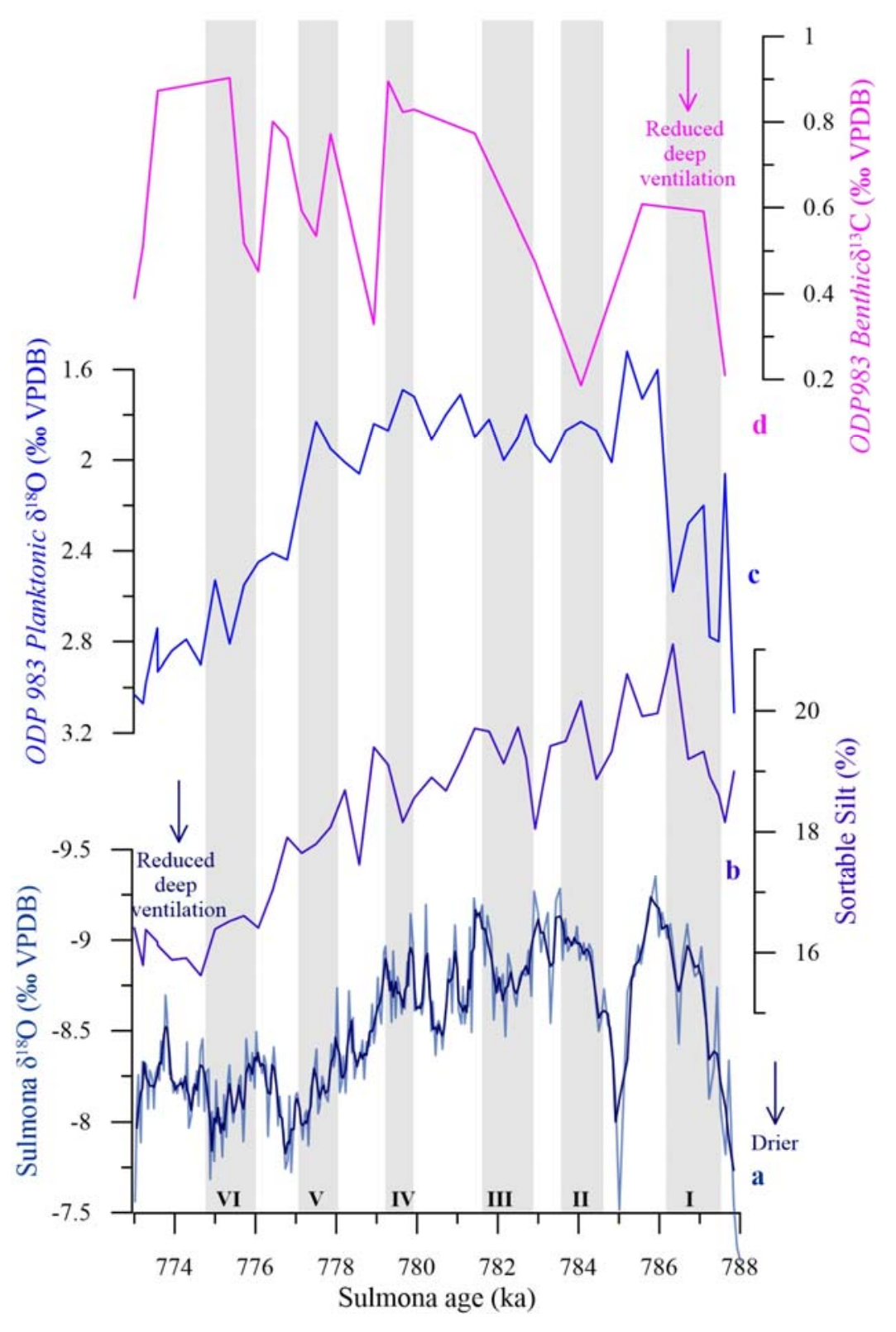

942

Figure 8 


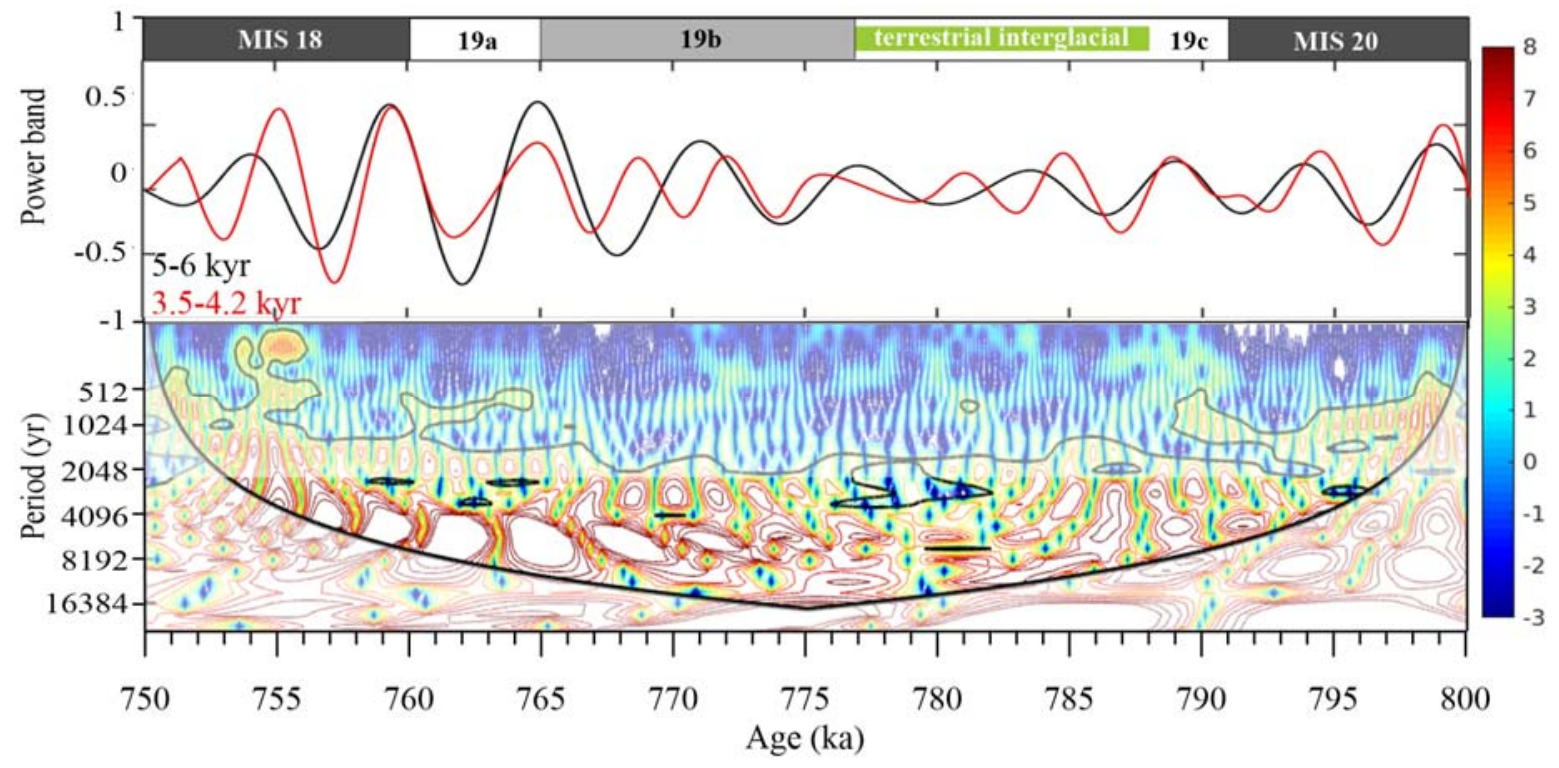

944

945 Figure 9

946 